University of Louisville

ThinkIR: The University of Louisville's Institutional Repository

Electronic Theses and Dissertations

1949

\title{
A study of human relations in the fifth grade in I.N. Bloom School.
}

Mildred Hargraves Bott

University of Louisville

Follow this and additional works at: https://ir.library.louisville.edu/etd

Part of the Education Commons

\section{Recommended Citation}

Bott, Mildred Hargraves, "A study of human relations in the fifth grade in I.N. Bloom School." (1949). Electronic Theses and Dissertations. Paper 2351.

https://doi.org/10.18297/etd/2351

This Master's Thesis is brought to you for free and open access by ThinkIR: The University of Louisville's Institutional Repository. It has been accepted for inclusion in Electronic Theses and Dissertations by an authorized administrator of ThinkIR: The University of Louisville's Institutional Repository. This title appears here courtesy of the author, who has retained all other copyrights. For more information, please contact thinkir@louisville.edu. 
UNIVERSITY OF LOUIBVILLE

A STUDY OF hUMA RBIATIONS IN THE PIFTh GRAD

III I.H.BLOOY SOFOOL.

\author{
A Diseortation \\ Bubaltwed to the Faul ty \\ Of the Graduste Sanool of the Untromelty of Loulevi21e \\ In Partial Fulilinent of the \\ Requiremente for the Desree \\ of Nater of Banostion
}

Department of Education

By

M11dned Hargereses Bott

Yoar

1949 


\section{UHE UNWvessir LIBRARIES}

This PDF document is a scanned copy of a paper manuscript housed in the University of Louisville (UofL) Libraries. The quality of this reproduction is greatly dependent upon the condition of the original paper copy. Indistinct print and poor quality illustrations are a direct reflection of the quality of materials that are available for scanning. The UofL Libraries greatly appreciates any better copies that can be made available for replacement scans. 
NAME of STUDEAT: Mildred Hargraves Bott

TITLE OF PROFESSIONAL PAPER: A STUDY OF HUMAV RELATIONS In THE FIPTH GRADE IN INABLOM SCHOOL

APPROVED BY READINO OOMATTEE COMPOSED OF THE FOLLOWING:

Ruth Dunn

Noble H. Kelley

HAME OF DIREoTOR! J. J. Oppenheimer

Dats: Clequis] 18,1949 


\section{AOKNOWLEDCEMENTS}

The writer Is graterul to Dean J.J.OppenheIwer. whose oonstruative oriticlam has proved invaluablet to Mia Ruth Dunn, whose philosophy of oduoation has ane much toward ahanging the miter"s att1tude to huanan rolationst to Mr. Ray Bixier, for introducing the miter to many now phices of the teohntque of group thorapyt to Mien Bore Kelley, whose unfalling interest in Roon 11 has wade it poselble for the writm er to oarry on this experinent and to the cless in Room 11 for tholr cooperation and intervat throughout the year. The writer withes also to express appreoIation to Dr. Hoble H. Kelley for his kindnoss in readIng this paper.

$$
\mathrm{M}, \mathrm{H}, \mathrm{B} \text {. }
$$


TABLE OF CONTENTS

Page

PART I-m-PURPOSE OF THIS PAPRR-m- 1 Purpose

Coai 1

PART II-m-ILITERATURE RELATED TO HUMAN

RELATIONS IN OLASSROOM-1_-3

PART III--DECHAIQUES UBED WITH THE CLASS--m- 10 The soclometrio Test 15

Analyat of the Tables 19

Anulyal of the Soclometrite rest 25

Planned Aotivitles Between the Teets 30

Analyals of the Tables 32

Respenees Aftor the Jume rest 38

Comparison of the Soctomotric Teats 40 Autoblographl es 42

"HY Year At Bohool" 50

D1 soustons of the Auboblographles 58

PART IV---ACTIVITIES IN THE CLASSROOM-m-m-- 59

Dramatization: 59

Paychodrama 61

Muelo and Art 63

Cames 64

Dance Aotivities 65

Tripe 65

"Talent Shows" 66

Hobby Shows. 66

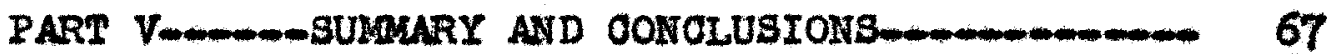
Summary 67

Conolusions 68

BIBLIOCRAPHY- 70 


\section{LIST OF TABLES}

Inse

Pese

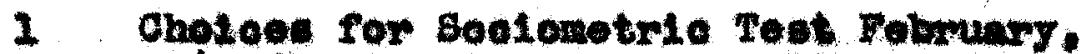
1949 Shwring the Ghooken. Firet. Second and Thimd chotoen tor 28 Boys and 19

QI 2 a $a-20$

2 Soglogrem Shoulns the Puret. Oholoe of 18 Dore una 29 cirte Cmiles 5,4\% IN. Bloon Sohool. Louler411e. February, 194921

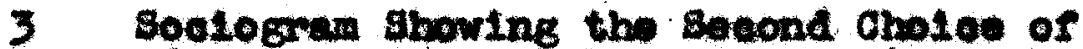

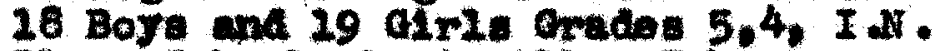
Bloon Sahool, Loulori210. Pebruary. $2949=0$

4 Dostogran showing the Thind Oholoe of 10 noys and 19 alle Grados 5,4. IN.

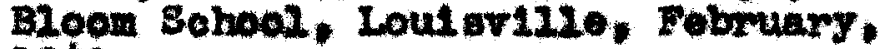

1949 -

5 Resulte of the Soelonetwle Teat Peburary. 1949 showling the Xtamber of Ptaes Eaoh of the 18 Boys and 19 G1r1s Was

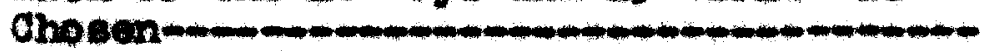

6 Regulte of the Intrivions Arter the Fob-

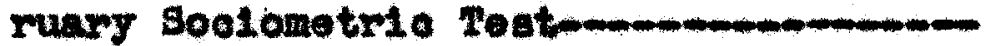

7 Oholees ror goolometrie reat Jume, 2949 Showing the Choosen. Firet. Beoond and Thim Oholoo for 17 Bors end 19 Girie.

8 Soologran Showing the Mrat Chotos of 17 Bore and 19 Girls Graden 5.4. I H.

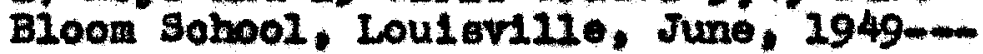


9 Soologran Shoving the Seoond Oholoe of 17 Boys and 19 Girl Crades 5,4, I. A.Bloon Sohool, Loul Ev1210, Jume; 2949 -

10 Soolegram Showing the Third Choleg of 17 Boye and 19 atria Oraden 5,4 . I 4 .8200n Sohool, Loulev1110, June. 1949 -

11 Reoults of the Soolometrie Test June, 1949 shenting the Number of Times Hach of the 17 Boys and 19 Gr2s Was Ohosen 


\section{PART I}

PURPOSE OF THIS PAPER 
PURPOSE OF THIS PAPER

The writer's purpose in ohoosing this tople was to try to alsoover how to further good hum relatione in the olaseroon. Thls quotation from Adxentures in 1 Human Relations coemod rolovant to this otudr:

"People do thing to us. Thoy may bo happy. ploasant things. They may be unoomfortable, deresteting things. They may bo at1mulating, ohalienging things. They may be things that restere our pol se. Inorease our fal th and atrengthen our convietions. They may give us new perepeetive, now courrage. They nay wbmerge us into doppalr, and fonr and poselntom."

If this be true how Laportant it beoomes to study the erfoets that people have upon osoh other. If this be true 1t beoomes Important for people to learn to Ilve with thomeelrea and others.

With this as a goal tho writor kept in wind the point of observing elosely all intermotion wherever pose1ble. It also seonod good plan to give veveral soe10notrie toets. Although realizing the inadequacy of trainIng long this ino the toacher attempted to gain somo knowledge of the puplis through Pajohodram. Thls paper w11 try only to reoord the happenings in the olessroom. Thle paper vas not eesened to prove that human relations

2

Bullotin of the Assodiation for Chlzahood Edueation, Adrentumen in Eman Relationg. Washington, D.0.: p.14. 
are Improved by any of these procedures. In a yoar it would hardy seen posalble to eheak on this Browth adequately. It soemed to the teacher as if there wore groator woclal Intervotion at the ond of the year. wore cooporation and wore welf atsolpline, but as stated before this was just an opinton based more on feelings than on anj conorete ertalonas. 


\section{PART II}

\section{LITERATURE RELATED TO HUMAN FELATIONS IN OLASSROOM}


LITERATURE GGLATED TO HUMAX RBLATTONS II OLASSROOM

Touoher oan important englneore of muman brotherhood. Where oan the ahild better learn the value of himself and others? Every teacher oen have an effoot on his pup11. in many wars. Pup12s learn to velue certain things and to rejeot othors. The tesoher can influenoe the personallty of the ohild. Fron a teacher the child often gete his attitudee toward himbelf and others.

If our domocracy 1s to ourvive and not be lost all of the ohliaren of all of the people aust underatend the basio prinolples underlytig our form of domoormey and mut noquire the artile neoessary for domoeratio IIVIng. This cones only through praotice and through experienoe in such IIving. Democraoy eannot be teught unless demoeraoy is 117ed in the sehools.

A. a demoerat1c atmonphere energes, all members of a group oan be oncouraged to uhnre in developing problem that noed to be alsoussed and olarifled. Whon a fov poople cooperate with each othor and act togother for the achiovement of a oommon goal, they oreate a runotionlag group. Thoy have disoovered that group produotivity gets wome thinge done that could not be cone by indiriduals working alons. Differences of oplntion, exchange of ldeas, and Injootion of now values atimulate ohange in the beharlor of 2 inaividuara.

1

John Dewrey Soe1ety, Berenth Yendmook. New Yorki The MacMilien Coupany, 2948, DP. 2-7. 
When all Individuals have shared in the prosess of arriving at a deolitin everyone is $11 \mathrm{kely}$ to foel nore responsibility for the execution of the plans. All too orten a majority mule 18 foroed on peophe. Group aetion 1. not efrective so long as the majority or the minority operees the group to aot. Ueually with Wise guleance group w11 cone to a consenous of oplnion.

Our form of domoernor eamnot long oxist without all Indivicuals doveloping their powers of leaderahip es vell as followerahip. Both rolos must be learnod and practioed.

4 good Group leader tries to develop leaderahlp quilIties in nembers of the group. He coerdinates the arforts of all members. Ho improves the hman relations. Ho roapecte the unlque contributions of each person. He is an accepted momber of the group and not the one orer all. For mang year eluentors have recognized that how a onild learns is in many vays as importent as, whet ho Iearne.

It beoomes apparent that leaderahlp through croup prooseces make defint to contributions to the "Way of Life", known a demoeraej.

Acooralng to Borgesen!

"Domporatie Hiting is a Gyamig. Erowing, ohanging conoept of human rolatienchsps".

1 F.0 Borgeson, "Loudorahls Through Oroup Prosese" the

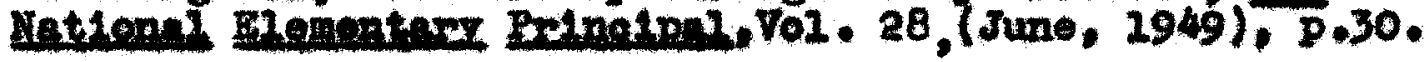


Anong 1tb elemente are renpect for personallty, oooperetive endeavor, self alroction and celf oraluation by the nombers of the group.

Tho olasmroom should be a laboratory in group 21ving. In modem touching the olass is a cooperative group whore pupll: and toacher allke are thinking through a tople, or carrying out an actirity. The now type oleserocm oalla for group al seusetion and group cotivity. All the benerits that come from group thorapy with montal patient are to be cound in the up to date diangroom eceording to the maga-

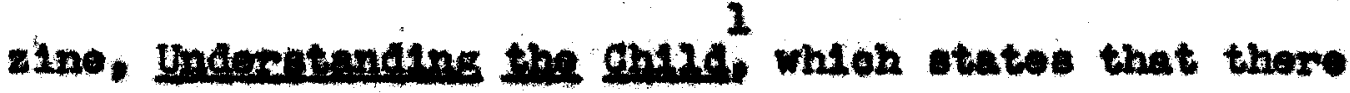
aro four benerite arrived from this, navols: I. Mur121mont of the pup11's basle emotienal neode, 2. Development of the vital sockal ak111s of solving problems oooperatively by group deounator and group activity. 36 Release of omotional tonstome and conpliots and 4. V1tal partiolpation of the pup12. in colving sohool and oommum 1ty problems.

One of the baslo noeds of ohlidren is the foeling or bolongling and of socoptanes. Where a aktlied towoher onocusages overy member to take part the proper atmogphore is oreated. In woh a elassroom one finds the ohllaron Iearning to IIoten roppettuly to the opinions of others, trying to underatand others points of vier and

I

The rational Oomattee for Kental Hyglene, Ino. Dnderteanding the onsta. (Apr11, 1947), D. 17. 
2eurning to help others solve thelr problene. Another of the baclo neode of the ohild 1 s the sonse of independenoe. Whore the teacher used to do woat of the talking and planning there was no roeling of the vory belng allve for the pup1ls. Ohildren normeliy dealre to have a ohare in the thinking, planning and in the actirities of the elesuroom. If the class is treated as a oooperative group engaged in solving prob20ms the pup12. are given an outlet for their neods for achlevement, recognition and self esteon. Erery ohlld needs to feel the taite of atwoese and joy in having his Ldeas oarried out by the group and of having his acoomplimbents win the approval of others. In a olaseroom 11ke this the pup1I Iearns the mot important ax121 roquired for the existenoe of our modern world-the bill of thinking. To wolve problens by cooperating with others who diffor in raoe, roligion, or soolal baokground is most Important. If the oleseroom 1 to be genulne laboratory of soolal 11ring the puplis aut learn about Just1ce, toleranoe, goodw11l, genorosity and respect for pereonality by practloing relationohlps with others that carry out those 1deals.

Good nental hoalth 16 desired for overyone. What doos thi moan but the ab111ty to attain and maintain atlefaotory human relation. The group wethod enables 
ohilaren to vork out their enotional tensions, their enxiet1es and tholr oonfiots. Worktng out rears, rosentwonts and botile foelings in a group whioh aocopte hit and under the guldanoe of a wise tosoher 18 a rery good exportence for the onlld. Through the Interohange of group opinion and through the help of a ayagathet10 toacher the pupll is able to understand the origtn of his reolinge and projudioes, Coopertitive group thiniting and activity by helping pupils to I1vo out thelr emotional probieas and confliots $\mathrm{x} 111$ do

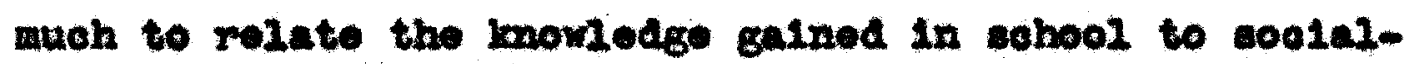
17 construetive destres and beliers.

Recent studies of ohliaren attribute to omotional alfrieultios some of the wont merlou coolal confliet: of our any acoording to Boyton. He otates further that there is eridence that the achool are eometimes - direot faotor in produeing delinquents. Back of nome of the conrilots of modern boys and girls is tho eloment of fear. Good mental hyglene meane applying to overything in orery ding what has boen learnod with regard to the bebavior of mamen belnge. For toachers and othors who work with chllaren mentel hyglene involves not enly a bottor understanding of humen growth and dovelopment with reapeot to those with whom they work, but al wo an underatanding of the worker's own pereonality and his relationchlp to his ranlly and associates.

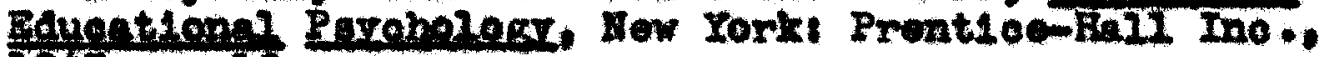
1945. P. 10. 
Tho alms of duoation and aental hyelene, should 1 be the anse secording to Frank. Thl should be the derelopment and training of the indiridual for erfeotive IIring. Both are conoemed with leading the chlld toward habite and attifudes that wake tho oblid bettor. able to attaok the problens of 11fe. Nentel hrelene also maks elear that the montal houlth of the ohlza way be comloudy endangered by the vay in which these $2 \mathrm{~m}$ terferences and doprivations, compulatons and problbstlone are taught to his. The porsonality of the ondid and his adjuetment to seotety copend upon the way ho

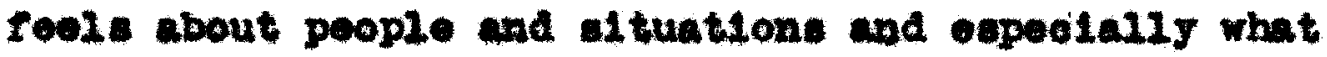
he thinke of himedr.

A program of human relatlon: becomen a moje alm of eduoation in a demoencer for, these reasons, 1 . Huan relations axe Iargely loamed resotions. If it is true that the undeafrable tract te are learnod then it 16 equally true that the proper roponses oan be teught. 2. The reare covered by the elementary and seocndary sohoole are the eritienl reare ror the learning of human rolations. I Iarge portion of the infinenoe exerted by the Bohool comes to the chtiaren as a total emotional olimate often apart from the regular instruetion. Thi Ie a compeste of the attitudes of pupt2., teaghers

$\overline{1}$

Lamence I. Frank, "The Orientation of Edueation to the Promotion of Kontal Hyetene". Kontel Iretend. (Ootober. 2959). Vol . 23, D. 530 . 
and the parents in the communt ty. Hev pupil ontering a uhool wi32 rind it arfloult to oppose an environment where those prosent are sensitive to the values of geod human relations, where the nombers are okilled In oodes of conduct ohnracterized by underatanding in which traditions of courteng and good will are estab11abed, whore there is a proteotive wenee of the etrong for the weak, and where the seboel and private property are hald in high eateen.

In most oldenrooms the foeal porson is the teacher. He should be the inctruotor. the oompanion and the all pervagtre influonoe. Ho thinking and attl tudes will stund as gulde poste to the conduet and thinking of the chlldron. Thorefore a tencher should be well bulaneed In all of his disousulons and in his denlings with the ohizaren he hould allow no projuatees to oreep in. He should mote out pratwe and blame in a falr way. Ho should be aenultive to the eppertunitles for the development of wholesome coolal 1iring. He should be vell informed through wle reading. Ho should have the know104ge that will be userul to hin in teaching muan re2at10ns. He should be oompotent in the neesasary toachIng tookntques. Above all bo hould be just and unblaged in his aearinge with othone."

$\mathbf{I}$

Pawl Boynton, Jom W. Oharles and Othore, Bommenrar

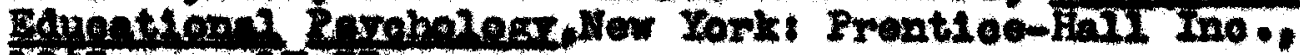
$1945 \cdot 9 p \cdot 17-33$ 


\section{PART III}

MEOENIQUES USED WITH TER GLASS 


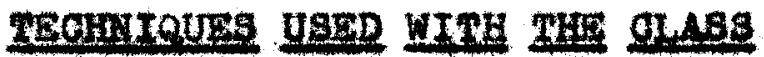

W1 th thooe points in mind whe of the human ralam t1ons in Roen $I I$ at the I N BLoon Sahools How could the writer apply those prineiples to the alesa? Mirst 1 t seemed that a soclonetrite teat would be belprul in dotermining those in the elase who were leadorw, those wo were cuevesarul in thelr relations with othere and those who were not. In all groupe thare are oleavages, between people who seem to be Alfrerent and those who cooept the studare, between Individunis whose lape of what is right and wat is rrong diverge. It is nooes any to etudy the croup in ordor to wo ways in which olearages ean be ellminated and how whils oan be doveloped for handilng those oo as to avold their perohologteal raste. A soologram, as a starting point, seemod to g17e cosaprohenstre rovelation of the group struoture. 4 soologram doseribea a oomplete ploture of spontanoou Interwet1on. Soelowetrio wethode put the attention on the dramies of Interwetion rether than on the aohleremonts of indiridual onildren.

Many teaghers have known the value of knowing the 2laes. They have studied the reeords, had Interview" obeorred the ahildren at work and at play, and have 11 stonod to the renarize about the olacumates made at rarlous

1

Helea Hall Jemnlngs, Banlonitior in Goun Rolnttons. Vachington, D.0.1 1948, Dp. I-10\% 
t1wes by the ohlidren. These things all proved of come ralue but it coemed thut 16 was impostible row this to know the endiaren who were really rejeoted and those the were the Ieddere. Often the teacher has been eurprised to Ioarn from a solomotrle teot that the ohild who seene west favomble to the faoulty is not the cholee of the pupils. Alvo 1 te way be proved that the ohild tho mote with 21 thle approval from the teachers is best 114a by the pup120. Th bast for this distingtion is not enally, underatood.

Many teachors have onoouxaged a ahild to work exalusively by and for himedr. This way be hararul to the ch114. those who learn to inditidualise all achievenent

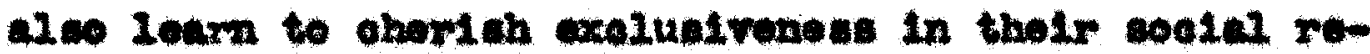
1atlons. Thoy are learning that they must guard tholr

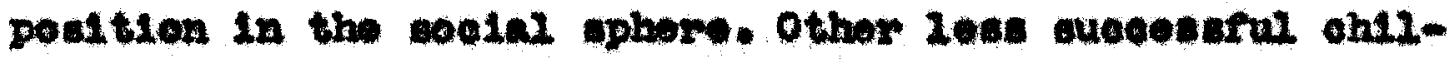
aren are learning to vitharaw * They may be rory robell10us, but they learn to supprese It. Thoy way beoove aIrald to try to eater social coora that are open to them. Both kinds of ohtlüren aro apt to cot exageerated opinLans about tholr own Inpertange and that of others. As ohilaren nature thoy poed arreotion trom members of thelr onn eroup, possibly more than they noed the apm proval of the toacher. They noed to grow in their ab111ty to approolate othors and to make alace for themeelves. They hould be given opportunt tied for the exobange of 
1deas, for holplng one another und for exploring the othor fellow' personality. Wh thout ouph exahnnge tholr Mille for oonted with others w111 be 11 alted and their

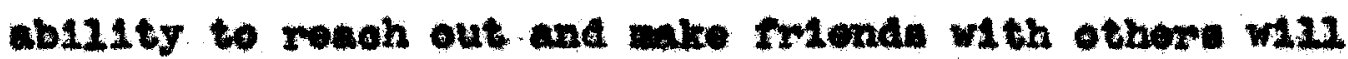
be innibltod.

Teachars have oftein conaldored it their duty to ceparate ohilaron who have how an interest in each othor. Senting plans, working oomattees and othor ar-

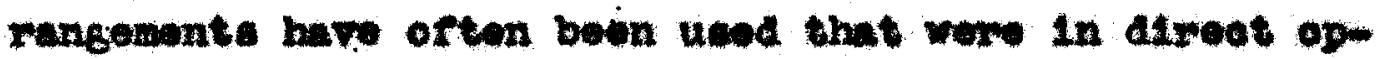
position to the dousres of the ohilaren. Many a alsolplinary problen has oome from the raot that the ollid ha: been foreed to 2ead tro 21vwe, one in the open and the other behind the teather' $\mathrm{g}$ bad.

The ane thing has bappened when ohtidren have vanted to holp weh othor. Thoy way be able to explain things to anothor child with sax more pationoe and okill than the teacher could bave. When this Inelination is thrarted much good is 20st. The ohild is taught that ho 1. to thind his own buatnest. In this was he is nover ablo to learn how catiafying this give and take oan bo nor is be ble to get the poreonal rolowed that cones from joint aot1on.

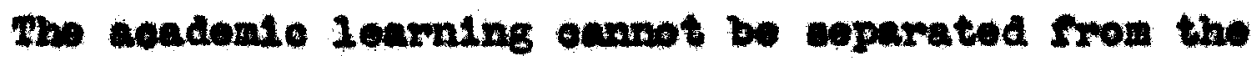
soolel atmonphere in which 1t tukes place. Stnoo ohilaren are taught in groups they are bound to arfoot each other. Tholr personal reelings and tholr attitudes to- 
ward othor. hwe a groat doul to do with the way they uae their ab111t1es. Glearage and tonslons may absomb eneres that eould hare been put to better use. Bxperiment: have show that when those blooks have been romoved usually the intellootual ab121ties are released also. Interaction in Broup allow the mewber. to complement one another and therefore may oontribute to greater total achsevoment. Indiridual oan stimulate each other inetead of oompeting ageinst each ather.

Under the prosent contitions the ohliaren found to suffer most in achool are the nembere of the winority group. who ueually are found in the rejeoted group. This may sauee lowering the prostige of this group in the ores of the other neabers. This may be juat as serlous for the onos in the oulturel oroup, for it is thil sort of consept that bringe forth the 1deat about the super10rity of certaln reoes end eocnomle groups and the Inadequacy of the othors.

As soon as woolal relations oun be studied they oan be gulded. Whon the teacher becomes amare of the exIatenoe of Interaction 1t is possible to build on It for ecuotional purposed and for greater enotional stabilsty.

In this next seotion the writor attempts to docoribe some of the experiences in conneotion with the 
24

coolomotris to st and some of the methods of interpretIng the results obtained. 
THE SOCIOMETRIC TESR

In proparation for the soolometrio teat, whtoh w112 work beat if the children do not foel that they must always work with nembers of the1r own Bex, the writer onoournged the ohllaron to talk freely about thelr feelings on the subjeot of working with all members of the class. In this sohool the tradition has been to have the girls and boye alt at alferent tables in the Iunohroon and to have them ine up in thiti order also. One of the boys in respones to the question, "Why do you think that the boys and GIrI con't want to sit togethersald. "I think thit In a lot of sohools the girls were wade to sit betwoen the boy so the boys would be geod. We were made to feel that this was punishment, 00 we nover wanted to alt by the EIrls. In the room we wore never allowed to choose our own veats." After the alsousaton the ohliaron agreed to try for wook haring the people alt in the lunchroom wherever they happened to oome and not to make any distinction. At the ond of the woek a rote was taken and out of the alase of 37 only 4 boys wished to go baok to the old way. The ohllaren were allowed to choose thelr own seats in the room. There vere no separate 1 ines when going from the room. After a fow woeks of this the teacher felt that the ohlidren were ready to take the soclowetrio toat. The ohildren were made to understand that this test was given for the purpose of holping then. Rappert with the 
ahilaren is a necessary prerequisite for using this teat. Tho test bituation must offor ohlidren opportuntties for choloes that are meaningtul to them. In thil altuation the children were used to working in emall committees, therefore the teacher anked them to Ilst on amall oard the three persons with whom they prefermed to wowk. They were told that no one would see the reewlts exoept the teacher; It was polnted out that it would not be posalble for everyone to got his tirat oholoe but that overy efrort would be mado to do 00. The wost important things to remombor about giring the test are: 1 . to inolude the motivating elements in the beginning remarks, 2, to word the question so that the ohlidren underetand how the reaults are to be used, 3. to allow enough time, 4. to omphealse that any boy or girl may be chosen, 5. to present the tost with interest and enthuslasm, 6. to asy how soon the arrangements baged on the teat can be rade and 7 . to keep the whole procedure as oasual as posalble. The test should bo eiven for an aotual purpose and the resultis should be uned as soon as possible.

After the teat the chlldren's oards were oheaked and rooorded 11ko this:

Ohlld's Name-Firat Cholee-Becond Oholee-Third Cholee

From this record the teacher made the soclogram. In order to do thi the writer ohose olroles to reprem 
sent the Birls and trianglos for the boys. Kemneth's oholoes were First, Donnie, Becond, Bernie and Third, Davia.

The witer ohose to male a soclogram for esch oholoe. If one has a large enough space to chart the soologram it may be Interesting to soe all cholces on one paper, but for this plece of work 1t seomed w1ser to ohart each one separately.

4 carerul look at the soolograms w121 roveal much Information about the interaotion in the group and help the teacher in planning further work with the alass. The writer felt that besause of knowing the 1solates in the group it became easier to arrange waye for them to be helped to beoone more soclal. The popular chlldren were easy to locate also.

In the fifth grade the internexual choloes are almost totaliy missing. The group is usually split up into two separate groupe of boys and girle. The motivations are besed on similarities of tralts, Ineluding phyalan, mental. soolal standing and of intereats in oomen pursult. W1 th the boys thore Is much more hero worshtp shown and with the glrls thore is usually muah enotlonal frlendahtp. Most of the oleavages are uaunliy beonues of nationallty and soclal class.

This eroup proved rather typloal of the reaults obtained in most flfth grades. There wero fow exceptions: 
Nary Sue, the daughter of a dootor, ohose the onildren from the Orphan's Howe, and there wore more boye and 81rle ohoosing each other. This way have been due to the diseussions held before the test. 
ANALYSIS OF NES TABLES

The following Tables were made after the Fobruary Soclometrio Teat. The writer relt that it would be helpful to have all of the rables pertatuling to the Test together.

Table 1 shows the flut atep after the ohlidren have mitten thelr oholees.

Tables 2,3 and 4 are the Boolograms.

Table 5 shows the number of tines woh ohlid was ohosen.

Table 6 gives the results of the interviews which were carried on after the Teat. 


\section{TABLE 2}

\section{SOCIOGRAM}

SHOWING THE FIRST CHOICE OF

18 BOYS AND 19 GIRLS

GRADES 5,4, I N .BLOOM SGHOOL, LOUISVILLE

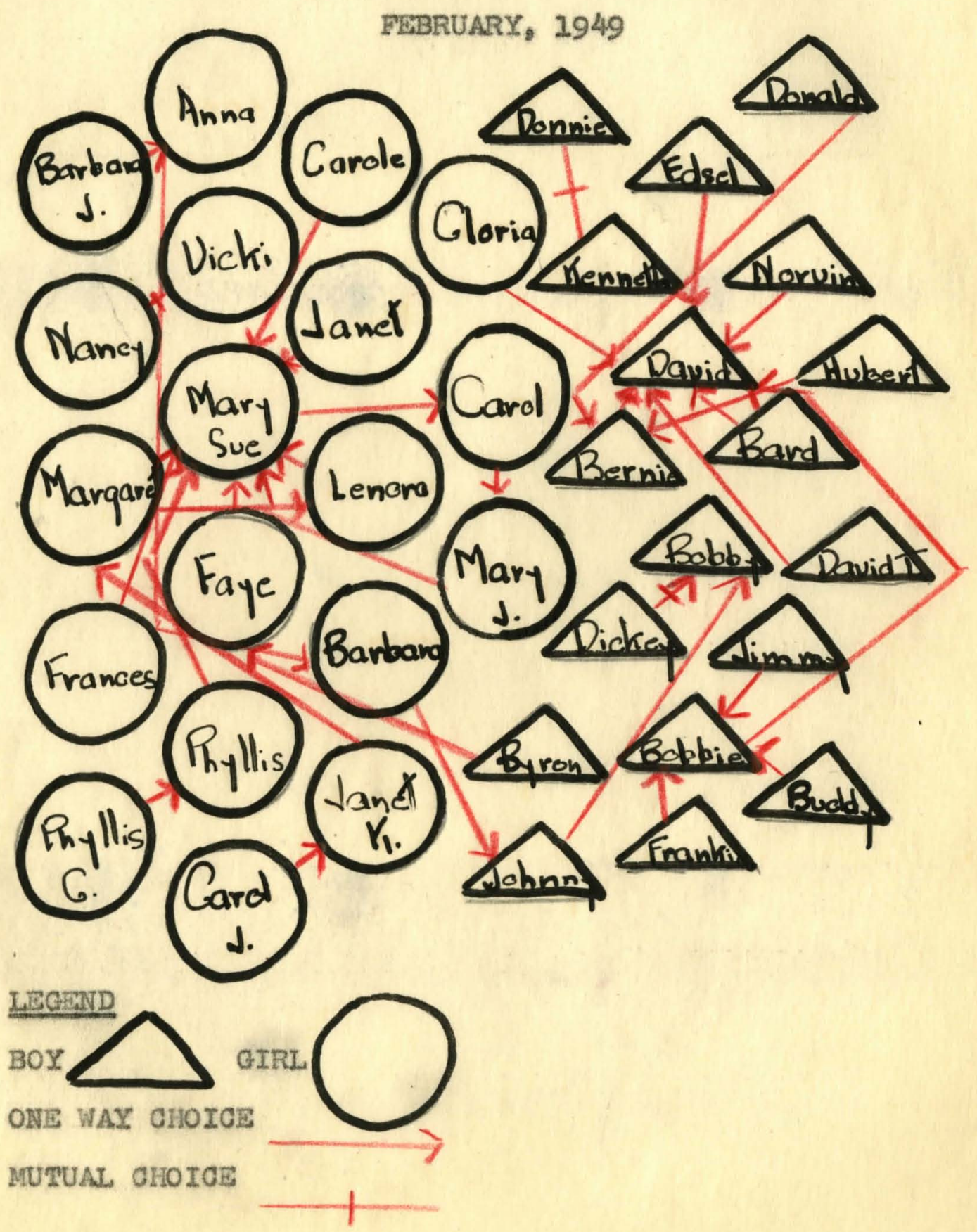




\section{TABLE 3}

\section{SOCTOGRAM}

\section{SHOWING THE SECOND CHOICE OF}

\section{BOYS AND 19 GIRLS}

GRADSS 5, 4; I dN .BLOOM SGHOOL, LOUISVILIUE
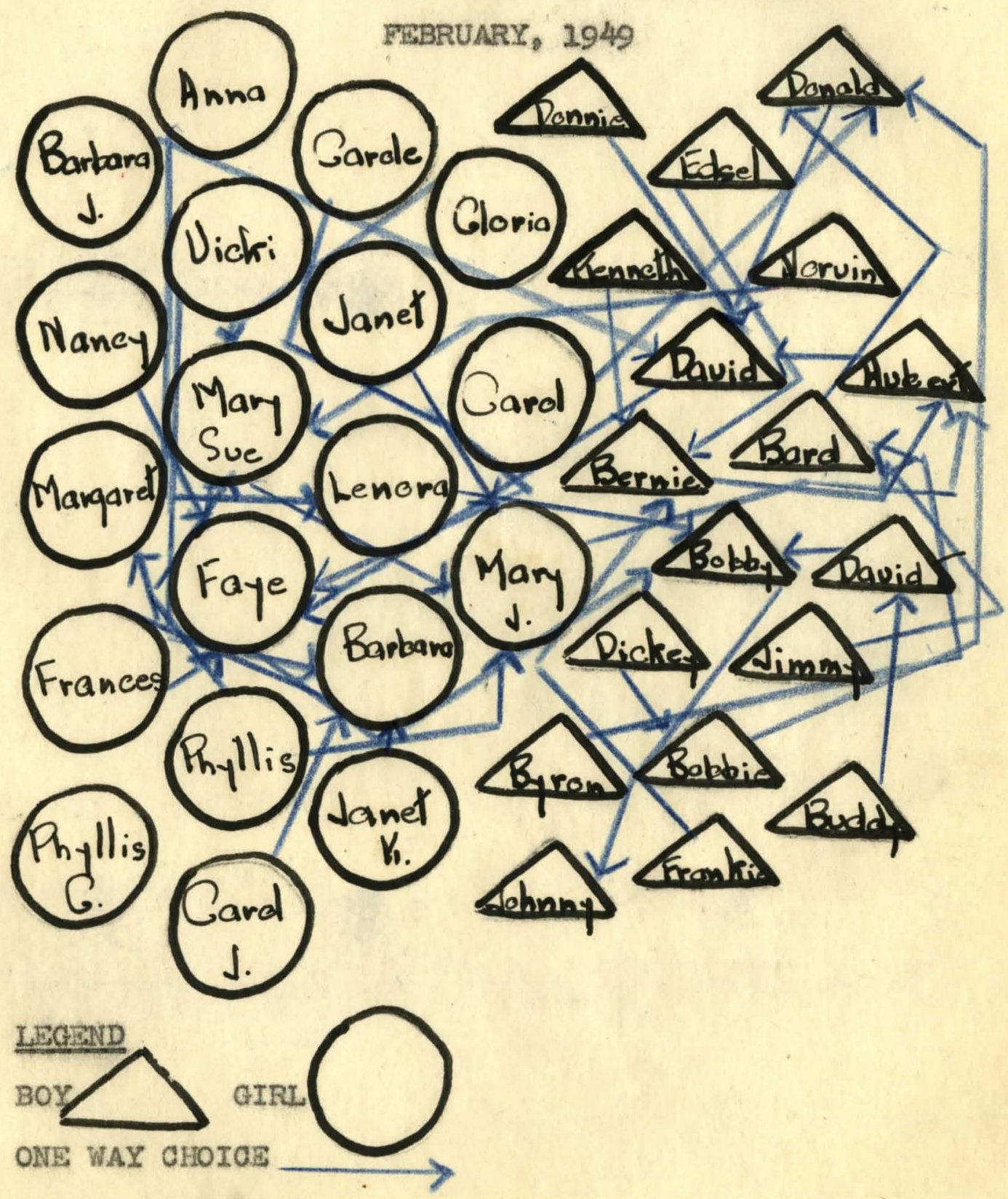

MUTUAL CHOICE

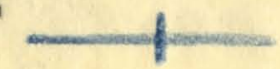




\section{TABLE 4}

\section{SOCIOGRAM}

\section{SHOWING THE THIRD CHOIGR OF \\ 18 BOYS AND 19 GIPLS}

GRADES 5, 4, I N .BLOOM SCHOOL, LOUISVILIE
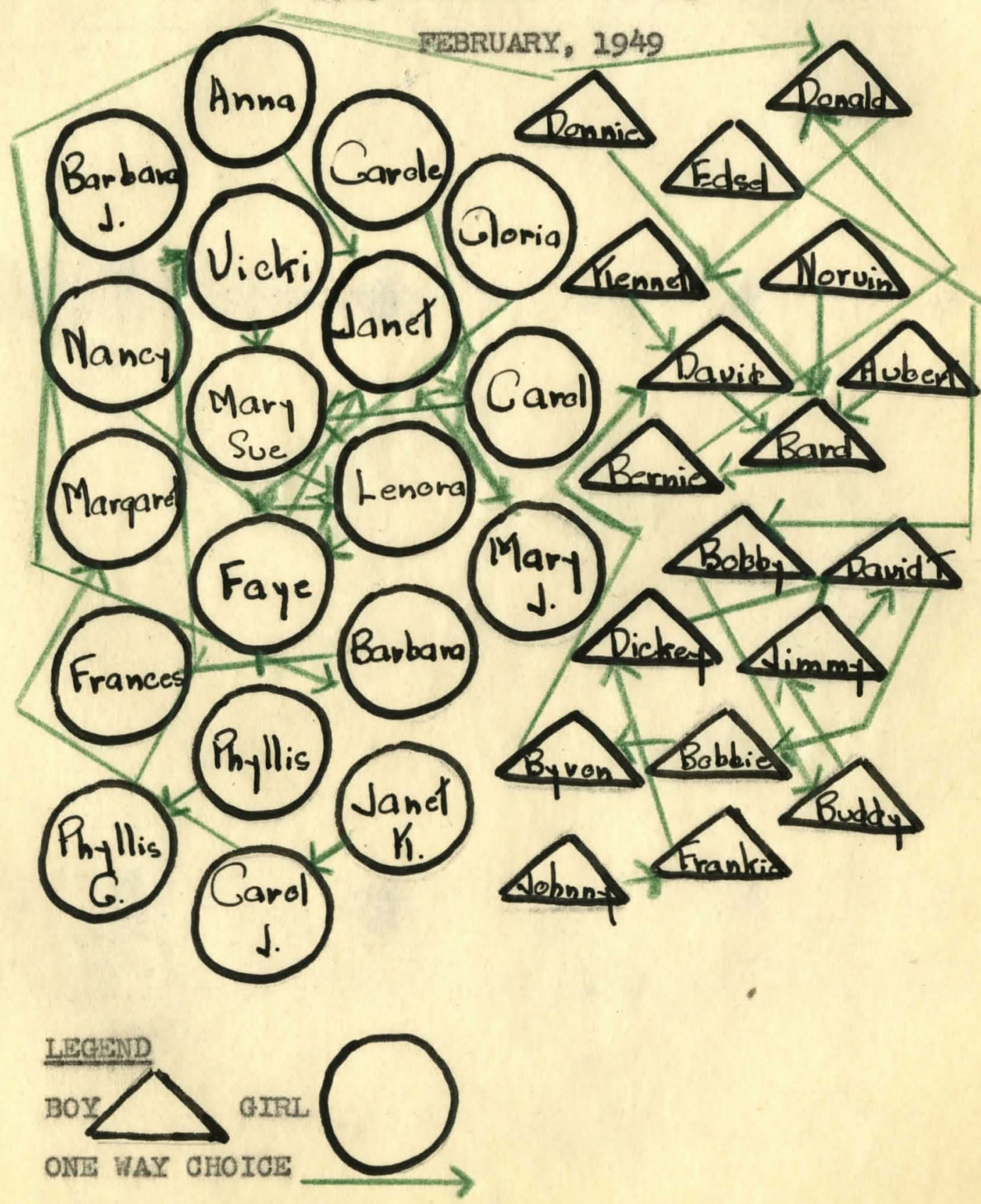

MUTUAL CHOTCE

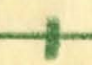


TABLE 5

RESULTS OF THS SOCIONETRIC TEST FEBRUARY, 1949 SHOWIKC THE NUMBER OF TIMES EACH OF THE 18 BOYS AND 19 GIFLS WAS CHOSEA

\begin{tabular}{|c|c|c|c|}
\hline HAyEs & I OHOICE & SECOND CHOTCE & THIRD CHOIOE \\
\hline 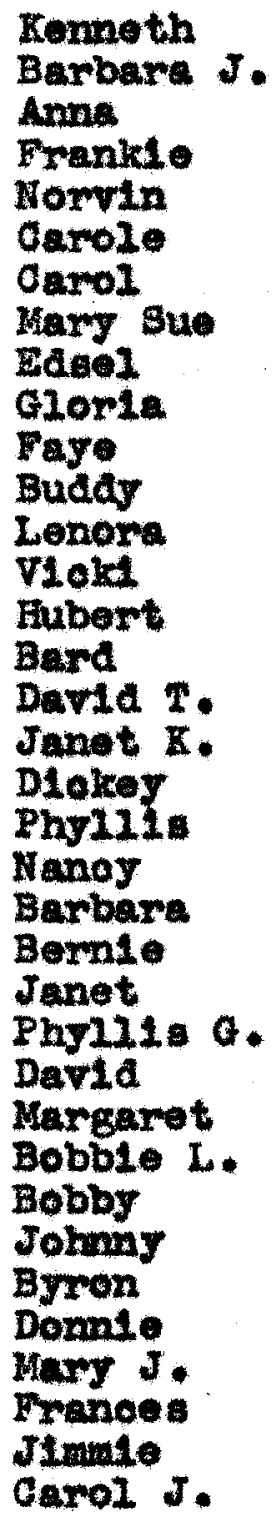 & $\begin{array}{l}1 \\
0 \\
1 \\
0 \\
0 \\
0 \\
1 \\
7 \\
0 \\
0 \\
1 \\
0 \\
1 \\
1 \\
0 \\
0 \\
0 \\
1 \\
1 \\
1 \\
1 \\
1 \\
3 \\
0 \\
0 \\
7 \\
1 \\
3 \\
1 \\
2 \\
0 \\
1 \\
1 \\
0 \\
0 \\
0\end{array}$ & $\begin{array}{l}0 \\
0 \\
0 \\
0 \\
0 \\
0 \\
0 \\
3 \\
0 \\
0 \\
4 \\
0 \\
1 \\
0 \\
2 \\
2 \\
1 \\
0 \\
1 \\
0 \\
0 \\
4 \\
3 \\
0 \\
0 \\
4 \\
1 \\
1 \\
3 \\
1 \\
0 \\
0 \\
3 \\
0 \\
0 \\
0\end{array}$ & $\begin{array}{l}2 \\
0 \\
0 \\
1 \\
0 \\
0 \\
1 \\
2 \\
0 \\
0 \\
2 \\
1 \\
2 \\
1 \\
0 \\
3 \\
2 \\
0 \\
1 \\
0 \\
0 \\
2 \\
1 \\
3 \\
1 \\
2 \\
1 \\
1 \\
1 \\
0 \\
1 \\
0 \\
1 \\
1 \\
1 \\
1\end{array}$ \\
\hline
\end{tabular}


ANALYSIS OF THE BOOIOUETRIC TEST

1. What appear that you had expeeted would appear? In examining this soologrum the vriter found that the children who had eppeared to be rell liked were chosen often. The Girl named Mary sue and the boy named David had 7 flrgt oholees and 2 third choloes each while Mary Sue had 3 for second and David had 4. There were several chllaren not ohosen at all, Edsel, Barbare J., Glorla, Carole and Norrin. The teacher had expected these ohllaren would not be ohosen. 2. What appears that you had not expected to appear? There were some surprises, for the writer had expected Jomny to get no votes and Mary J. recelved more also than 1t seomed she would. One girl, Phyll1s, who is very attractive, recelved only one rote. 3. What seeme to acoount for certein pup11s being the most chosen and best Ilkod?

In disousaing the qualitios necessary for a leader some of the ohildren sald that they liked Darld because he was cooperat1ve, a good worker, a good sport, Just about everything one could want, and someone who could be aepended on. Most of the ohllaren chosen often seemed to bave these same qualities. 4. What oems to account for oertain pup1Is being unchosen?

Edsel is a boy from the Orphan's Home. He 18 able to do 
Good work, but he is rather brusque in his manner. Carole 1s now to the school and does not know how to make Iriendi, She trien to attract attention by odd mothods. Barbara J., at one t1me, seemed very populax with the boys. Hor mother alsoouraged hor Interest in thom and the girls seom not to be vory oonsolous of her.

5. What seems to acoount for the mutuai oholoes? The onhdren who ohose eioh other 12 re near and play together. Thoy seomed to be the ones who work and play together in the room. 6. What aleavages appear in this soologran? GLorla and Franklo are Jew1 bh ohildren. Frankie orten coments on rellgtous prejudtoe. There are several ohilaren from the Orphan's Homo. There are several oklldren whose fathers are doctors and lavyers. The ohllaren from the Howe are treated kindly by the others. Mary J. and Carol were both ohosen by Mary Sue who was the most ohosen gerl.

7. What do the jority of the most ohosen ohildren have in combon?

Tho miter belleves that most of the popular chilaren have the kind of personality that makes them fun to be with. They are kind and cooperative and not too self ocntered. They are able to projeot themselves into the altuatlone of othor chllaren. They are good aotors and 
are alvaye roady to take part in enjthing. 8. What do the unchosen ohildren have in common? Most of those ohllaren are quiet, laok self confldenee, are unable to do good work, are unoooperative and hardiy ever volunter to partiolpato in any aotivity.

The soclogram ean show only the structure of interrelation, but not the resons for this. The soologram showa whioh ohildren aro 1,olated but it does not reveal why the oholces were made. It gives an intereating ploture of the soolal atruoture, but nothing that can be used for the indiridual or for the remeducation of the class. The inner reasens must be diseovered by the use of additional derices, since 1t 18 these that must be ohenged if better group atmosphere is to be present.

One of the devices used by the writer was that of Interviewing the ohilaren. It is 1mportant that the question be worded correotly so that the ohlid w112 reapond properiy. The ontld should not be made to foel that hl a choloes are belng or1t101zed. Ono way that the question may be aaked 1s, "Could you help we to find out how you happened to ohoose Mary Sue for your firat oholoep" Tho ohilaron should not be made to feel that they have to justify their remarks. The answers should be treated serlously. It 
1. good to prosed alomy and selse an opportunity to talk to the ohlidren whon they geem in the mood to tell the toacher more about their oholoes. In view of the fact that many of the ohlldren in this class gare about the sane reaponses the writer folt that these could be clessifled under the headings and the number of times they were mentioned could be 11ated 2100. 
TABLE 6

RESULTS OF THE INTERVIEWS AFTER THE

FEHBRUARY BOCTONETRIC TEST

Cooperation-D-n- 12

Is KInd-1-n- 8

Fun To P1ay W1th-n-mans

Good 3portm-1-man-m 4

Friendly-20 4

НеХр日 Ке

Is a Q00d Playex-m-n-m-

Total - 37

From this the teacher was able to see that the most important polnt to the ohllaren seened to be that of oooperation. Sinoe this had been stresed in the room sinee september this ald not seom strange. Many times during the your the ontlaren had opportinitles to talk wbout what they Iikod about their friends and kinoness was brought out orten. This olase was made up of some good ball playera so the remark, "fun to play wth". wht well have been expeotod. 
PLANITED AOTIVITIES BETWEAN THE REBRUARY AND JUNE SOCIOKME2IO TESTS

S1noe the first Soclometrle Teat was given in February and the ecoond in June there was an interim of several months durling whloh time the teacher planned definite training along the line of human relations. Aotivities that promote interaction and the use of demooratio mothods ald muoh toward alding soolal derelopment. The teacher took the ohlldren into partnership Instead of treating them as flling station. The writer tried to dovelop a realing of group belongImgnest. She tried to make momledgo come allve by pup11 partlelpation and group sharing. She ade an efrort to find out the noeds of the ontlaren and to help them over some of the obstacles that always seemed to $200 \mathrm{~m}$. She tried to develop the vital oolal dkills of solving problem oooperetively by group discussion and activity. There was ample opportunty for the release of omotional tenalons and the bullding of conetructive soolal attitudes. The toacher ondeavored to fulf1l1 the neede of the ohildren for seourity. Independenoe, echtevenent, reoognition and self onteem. Above all the writor hoped that overy ohfld had the feeling that ho was acoopted. The ohtldren were culded along the line that everyone had contributions to wake to the croup and that they would not 211 be the same. The writer kopt in mind that one Iearns better when one 1s happy and the atmosphere 
of the roon was geared aeoordingly.

During this time there wore many opportunities

for group work. There was group planing for prograns and comittee vork. Group eal disolpilne was dereloped to a exeat degree. The ohllaren seomed to be gainIng a better understanding of the causes of group beharior. They oertainzy gained lalis for effeotive group action. 
AHAYSI OF THE TABLEQ

The following rable were oomplined after the June soolenetwo Teat. It proved interesting to courpare the resulte of the two sests. It was eas to do the by usting the wame kinds of Tables.

Table 7 mows the firet step after the ohilaren have mritten thetr cholees. Table: 8,9 and 10 are the soctograms. Teblo 11 show the rumber of tiwes ench ontla was choeen. 
TABLE 7

CHOIOES FOR SOCIOMETRIC TEST, JUNE 1949, SHOWING THE CHOOSER, FIRST, SECOND AND THIRD CHÓIOES FOR 17 BOYS AND 19 GIRLS

CHOOSER FIRST CHOLOE SECOND CHOLOE THIRD CHOIOE

\begin{tabular}{|c|c|c|c|}
\hline 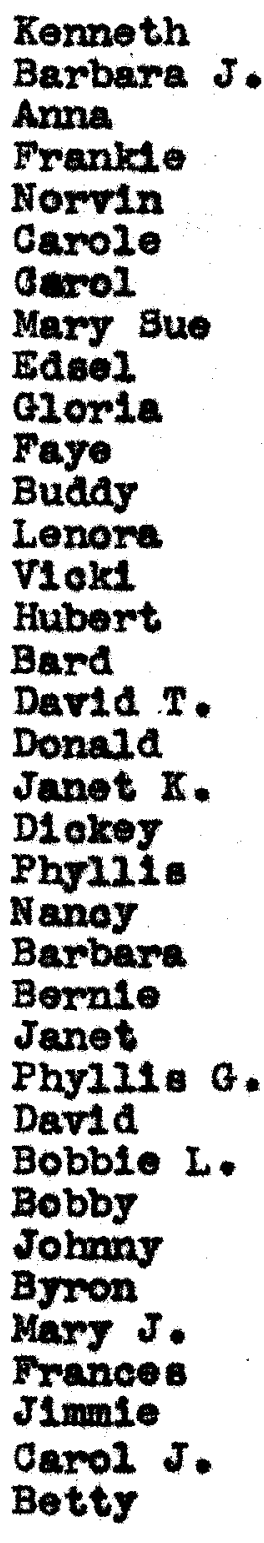 & $\begin{array}{l}\text { David } \\
\text { Faye } \\
\text { Donald } \\
\text { Mary J. } \\
\text { Darid } \\
\text { Faye } \\
\text { Bobby } \\
\text { Johnny } \\
\text { Barbara } \\
\text { Faye } \\
\text { David } \\
\text { Dav1d } \\
\text { Darid } \\
\text { Bard } \\
\text { Carol J. } \\
\text { Bobby } \\
\text { Phyl1: } G . \\
\text { Faye } \\
\text { Mary Sue } \\
\text { Byron } \\
\text { Mary J. } \\
\text { Phyli1s } \\
\text { Bemie } \\
\text { Donald } \\
\text { Johny } \\
\text { Bobby } \\
\text { Faye } \\
\text { Mary Sue } \\
\text { Mary Sue } \\
\text { Carole } \\
\text { Janet } \mathrm{K} . \\
\text { Faye }\end{array}$ & $\begin{array}{l}\text { Bard } \\
\text { Janet } \\
\text { Mary J. } \\
\text { Betty } \\
\text { Bobby } \\
\text { V1ok1 } \\
\text { Mary J. } \\
\text { Bobbie L. } \\
\text { Mary Sue } \\
\text { Franoes } \\
\text { Bermie } \\
\text { Bernie } \\
\text { Bobble L. } \\
\text { Dar1d } \\
\text { Lenora } \\
\text { Johnny } \\
\text { Mary Sue } \\
\text { Lenora } \\
\text { Lenora } \\
\text { David } \\
\text { Horrin } \\
\text { Barbara } \\
\text { Bard } \\
\text { Bernie } \\
\text { EdseI } \\
\text { Buddy } \\
\text { Dar1d } \\
\text { Janet } \\
\text { Barbara } \\
\text { Faye } \\
\text { Barbara J. } \\
\text { Mary Sue }\end{array}$ & 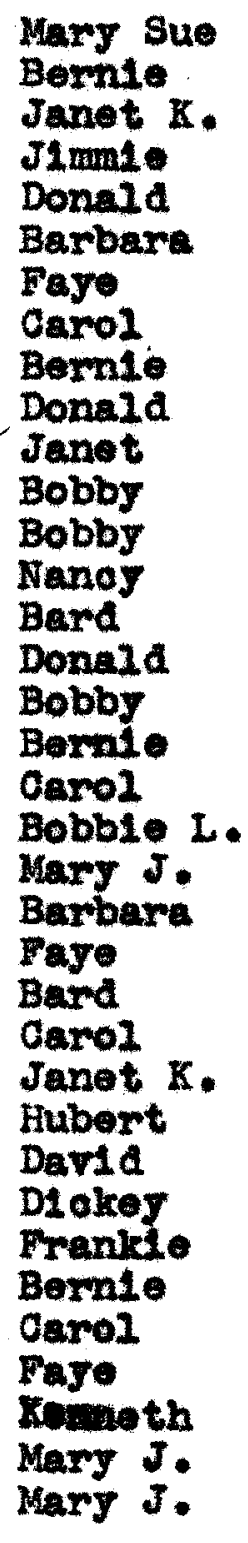 \\
\hline
\end{tabular}




\section{TABLE 8}

\section{SOCIOGRAM}

SHOWING THE FIRST OHOIOE OF

17 BOYS AND 19 GIRLS

GRADES 5,4, I.N.BLOON SGHOOL, LOUISVILLE

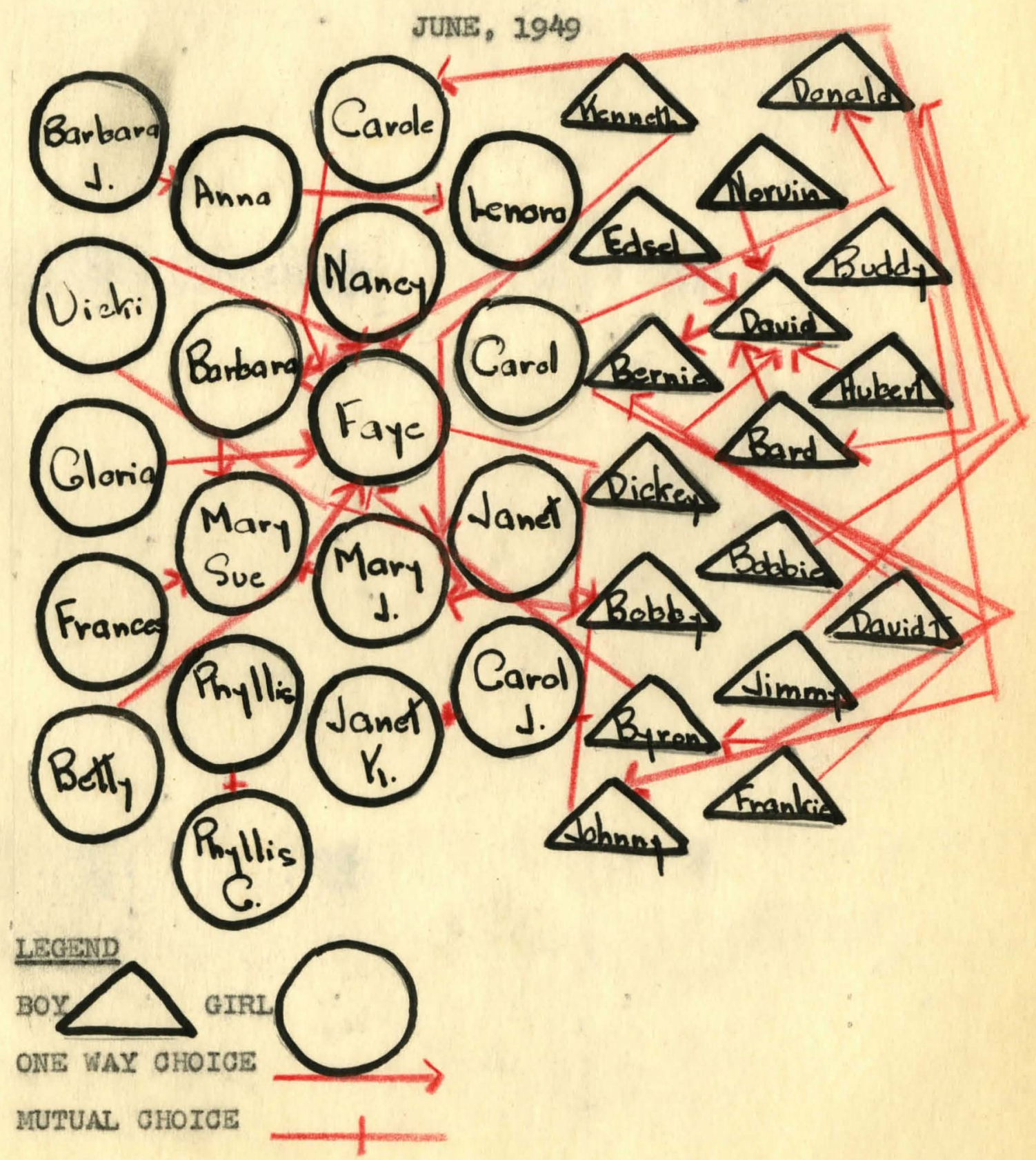




\section{TABLE 9 \\ SOCIOGRAM}

\section{SHOWING THE SEGOND CHOIGE OF \\ 27 BOYS AND 19 GIRLS}

GRADES 5,4, I AN .BLOOM SGHOOL, LOUISVILUE
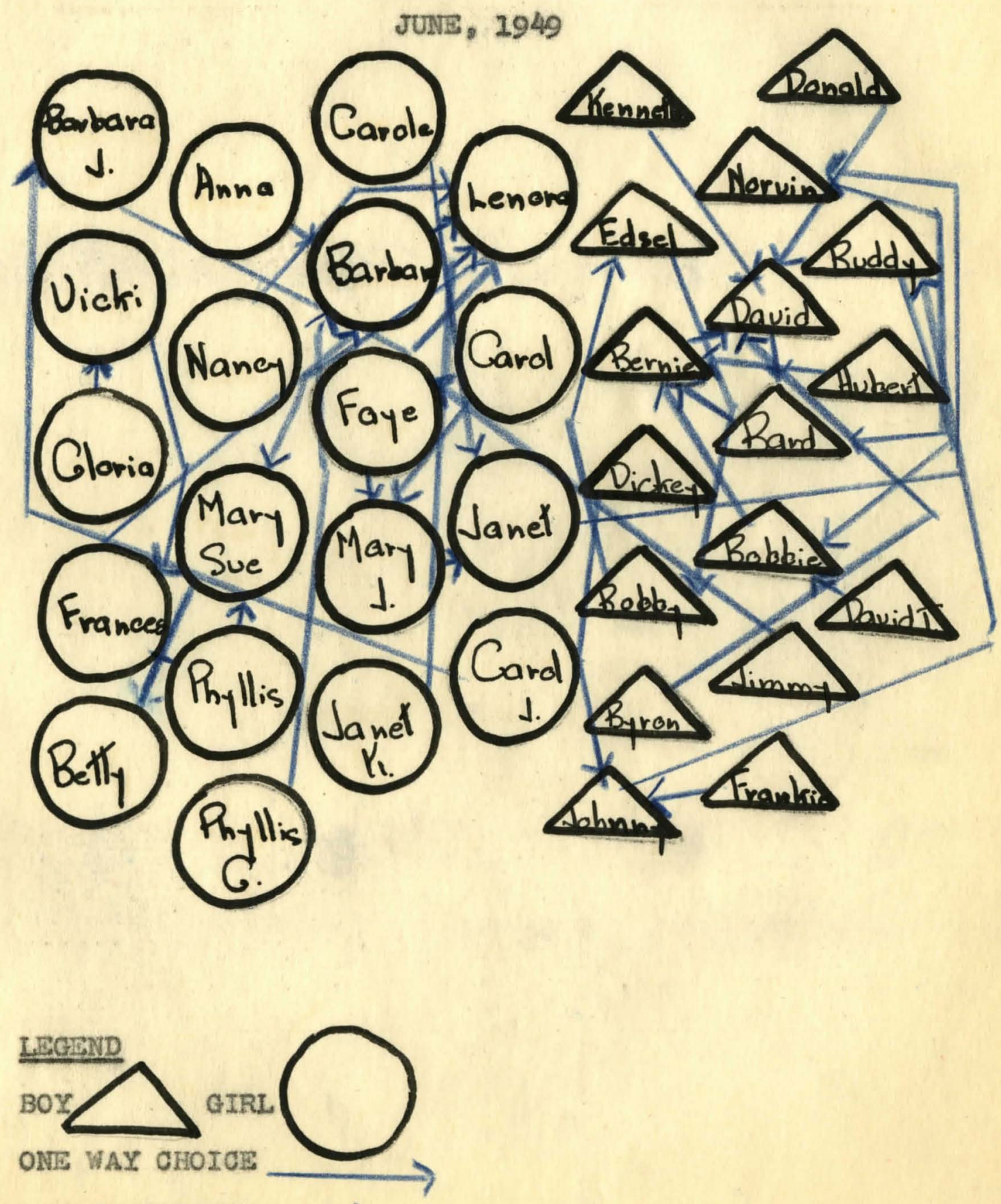

MUTUAL GHOICE 
TABLE 10

SOCIOGRAM

SHOWING THE THIRD CHOICE OF

17 BOYS AND 19 GIRLS

GRADES 5,4, I AN .BLOOM SCHOOL, LOUISVILLE
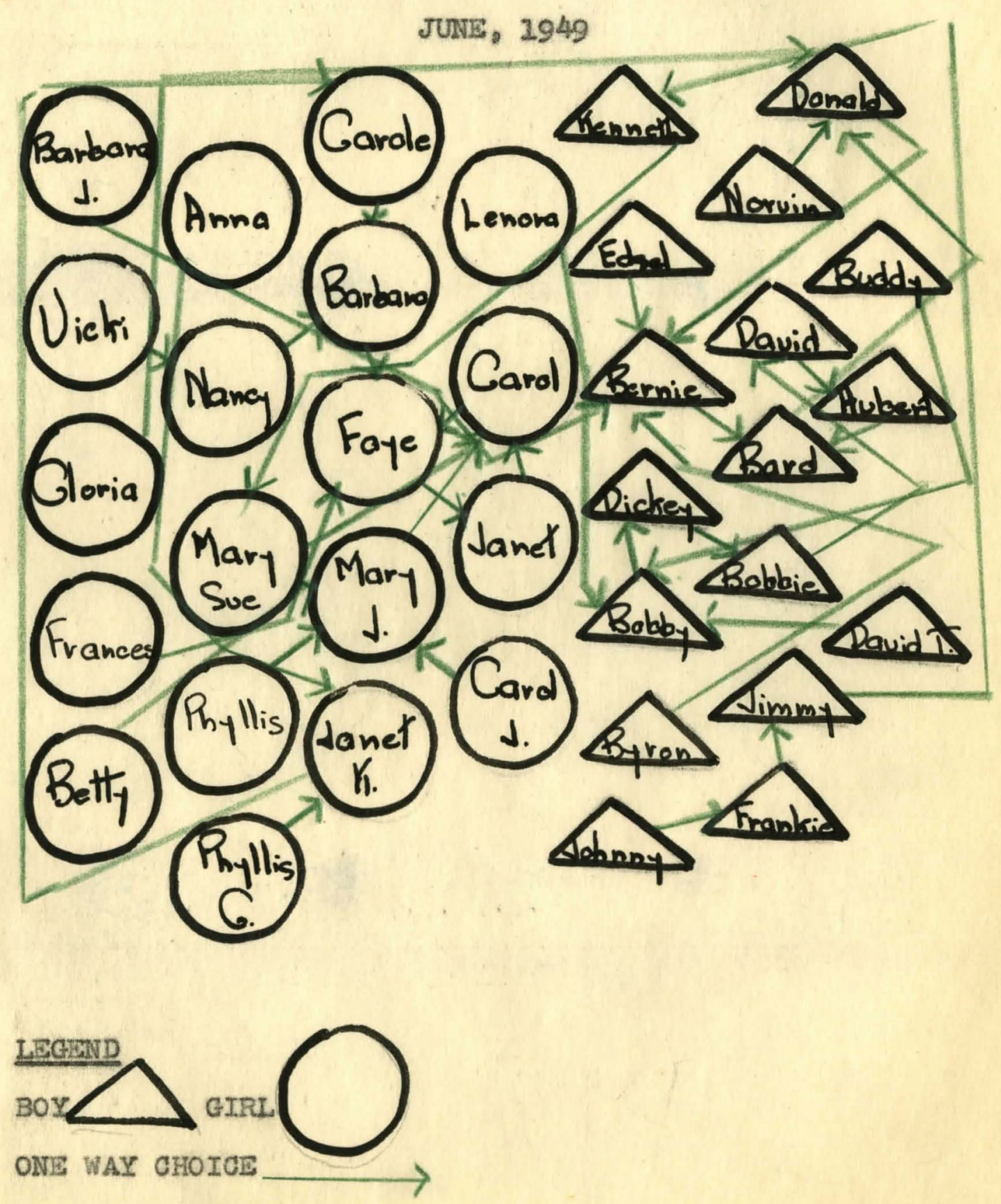

MUTUAL CHOICE

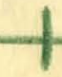


TABLE 11

RESULTS. OF THE SOCIOMETRIO TEST JUNE, 1949 SHOWING THE NUMBER OF TIMES EACH OF THE 17 BOYS AND 29 GIRLS WAS CHOBEN

\section{NAMES PIRST CHOICE SECOND CHOICE THIRD CHOICE}

\begin{tabular}{|c|c|c|}
\hline 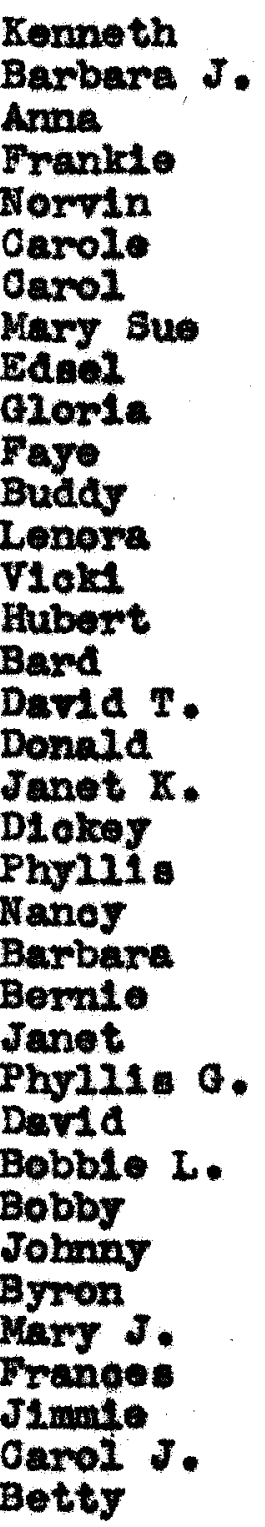 & $\begin{array}{l}0 \\
0 \\
1 \\
1 \\
0 \\
1 \\
0 \\
3 \\
0 \\
0 \\
6 \\
0 \\
1 \\
0 \\
0 \\
1 \\
0 \\
2 \\
1 \\
0 \\
1 \\
0 \\
1 \\
2 \\
0 \\
1 \\
5 \\
0 \\
3 \\
2 \\
1 \\
3 \\
0 \\
0 \\
1 \\
0\end{array}$ & $\begin{array}{l}0 \\
1 \\
0 \\
0 \\
1 \\
0 \\
0 \\
2 \\
1 \\
0 \\
1 \\
1 \\
1 \\
4 \\
1 \\
0 \\
2 \\
0 \\
0 \\
0 \\
0 \\
0 \\
0 \\
3 \\
3 \\
2 \\
0 \\
3 \\
2 \\
1 \\
2 \\
0 \\
2 \\
2\end{array}$ \\
\hline
\end{tabular}


RESPONSES AFTER THE JUNE SOCTONETRTO TEST

After the Jume Sooiometrio Teat the teacher arked

the class to write why thoy hed ohosen the person in

Irst place on their carde. These vere the responses

rooelved:

Kenneth-I 11ke Mary June bocause the 10 so kind. Barbare J.--I I1ke Anne beanuse she 1a gweet. Anna--I 11 ke Lenora because the does not not smart. Frankle-I 11ke Bernlo because ho does not teese mo and he shares the work and the oredit.

Horvin-I I1ke David beeause he has nearly 211 the points.

Carolo-I 11 ire Faye because ho is honest.

Carol-Ky cholce is Donald because he does hts work and does not got into trouble.

Mary Sue--I 11ke Mary J. because ahe is a good aport and cooperates with others.

Edsel--I 11ke David beoause he knows more than I do,

clomle-I 11ke Faye beoause the Is kind and holpa me at.

Faye-I I1ke Bobby beoause he 18 nioe and quiet. Buddy-I Ilice Johming because he is oooperative.

Lenora-My cholee 18 Barbara because the 1a nlee, Iriendiy and hoiprul.

VIok1-I Ilke Faye because she does not say what you have to do.

Hubert-I Ilke Bornie because he is eooperative.

Bard--I Ilike Darld beques he is eneerful.

Dav1d T.-I I1ke David becuuse he $1 \mathrm{~s}$ good sport. Donald-I 1lke Bard beouse he an make a good report. Janet I.-I ILke Carel J. beeause we go to the same churoh and hor father ploks me up every Sunday.

Diokey-I 11ke Bobby beoause he $18 \mathrm{kind}$.

Phyl118-I 11ke Phj111s $\mathrm{G}$. because she is not $111 \mathrm{y}$.

Nanoy--I 11ke Faye beckuse the 1s elways willing to work.

Barbera--I 11 ke Nary gue beoause ahe has ouoh outotanding self control.

Bernte-I $21 k e$ Byron because bo cooperates.

Janet-I 11ke Mary J. bocause she is never erumpy.

Phy111日 G.--I 11ke Phyll1s because she is nice to get along with.

Darid-I 11ke Bernie becaute he is easy to get along with.

Bobble I - I I ke Donald because he cooperates. 
Bobby-I 11ke Jolmay beoause he is mice and quiet. Johneny-I 11 ce Bobby beoause ho is nice and shares: things and take tums.

Byron-I I1ke Faye because she is not b111y and is never selrish.

Mary J.-I IIke Mary Bte because she 1. so kInd.

Frances-I IIke Mary Sue because she is kind and thoughteru.

Jimalem-I thint Carole is a good spert.

Carol J.-I ILke Janet $K$. because she $1 \mathrm{~B}$ good and kind.

Betty-I think Paye is arruils nioe. 
COMPARISON OF gOOIONEYRIO TESTS

The writor notleed after the June Soclometrio Teat that ame of the people who had been 1solates in Fobmuary had been chosen a rew timed. Bermie, Faye, Davld and Mary sue were st121 popular and a number of other ohilaren had reoelved more rotes than previounly. Glorla had remained an 1solate. Darld $T$, had beoone an 1solate. Ag there were several ohlidren who reoelved mo many votes 1t probably 1 an't posalble to judge whether some of the other ones would not get rotes in another group. The three outstending ohlldren, Dav1d, Faye and Mary sue all do excellent work. They have the ab1lity to make people Iile them. The witer notleed that these ohildren wore cheerful, confident, fuli of fun, kind, thoughtful, courteous, generous, oooperative and honest. They played vell, danced well and loved having a good time. They were clean and well dreased. The ramilies of these ohllaren were very cooperative, very interested in their children and in the sohool. These ohlidren seemed to have a sense of aequrlty that helped them to have confldence in themselved. The leolates or less chosen chliaren orten were the ones who came from large fanilles, suffered from an infertor foeling, wore timid and wharam.

The writer was not able to determine exectly why some ohllaren were popular whlle others were not, but there seomed reason to belleve that these quallt1es de- 


\author{
seribed may have been the eause. \\ In comparing the soolograms there did not seem to \\ be so much interaotion between the poups, but as stated \\ before this seemed natural for ohllaren in the fifth \\ Erade. The one who ot111 chose nembers of the opposite \\ wex were those who 11 red olose and oame to sohool in the \\ mano oar. \\ It seened to the teecher in observing the olass at \\ rooreation periede that thore were few ohildren who ever \\ leoked partnex and wany boys and girls telked and plajed \\ togother. \\ Thi olase sedmed to work well together and there \\ was much joy in ewoh other's accomplishents.
}




\section{AUROBFOCRAPHTES}

In order to Iearn wore about the ahliaren the team cher suggested that they make a personal reoord booklet. Some of the ohliaren oxlled these booklets by the names, "Autoblography". "My Lifo" and "My Reoord". As thoy had been working in Art on siblouettes someone suggested thet they use the alnlouette of themselves for the oover of the booklet. In order to do this onch ohlld chose a partner and each ohtld tried to drar the outline of hls partnor. They soon found that there were several ohlidren who vere able to make the athloustte look $11 \mathrm{ke}$ the person. This worked out very well and soon all the athlouettes were ready for the boeklets.

As a guldo these vere the questione doolded upon by the onliaren.

1. How many people are in your rabily?

2. What do you unually do arter sehool oach day?

3. How do you help around the house?

4. Do you take any loabons after sohool?

5. What gases and sperts do you 11ke beat?

6. What things do jou 11 ke to make?

7. What would you like to leam to de?

B. What are gour favorite books ind magasines?

9. What are jour favorite radio programs?

10. That kinds of novtes do you 11ke?

11. What do you want to be when you grow up? 
12. What interesting places have you visited?

13. What places vould you 14 ke to vialt?

14. If you could make two whes and have them come true what would they be?

For this paper the writer ohose to use excerpts From these ohlidren's bookst Darld, Glorla, Fayo, Frances, Mary sue and Norrin. Thls group Inoludes three chllaren whe vere very popular and three who were 1801eter.

\section{MORVIN-ISOLATE}

There are alx people in my ramily, my mothor, father. Erandnother, Erandfather, John my brother and I.

When I go howe from sohool I get out my bike and ride unt11 4:30. Then I ge home and do my homework. I 11sten to some programs on the radio unt11 $60^{\prime}$ olook. Then I oat my aupper. I 11 eten to the radto unt11 $90^{\prime}$ olook. Then I go to bea.

I help around the house by being quiet in front of the house. I oat good rood and do not waste 1t. I an quiot at night. I plek up my room. I ahovel coke. I run errands. I wash dishos. I entertain my brother.

On ruesdays and Friday I 60 to grm. I wiah that I could talke woodwork lessons.

I $11 \mathrm{ke}$ footbell, baseball and ahureloboard. I also 11ke Rusalan Bank, Gasino and Fua.

I I1ke to make boats, alrplanes and swords. I I1ke to make smoke bombs and fire bombs with my set of bomb 
explosires.

My favort te book are Bombe Avar. Herean end Out10ut. 100 Irloke of Hastatans and Ina Mratexy of the Pax 2 Eanah.

My favorite radlo programs are "Gangbusters", "Sky KIng". "Jaek Armatrong" "Iukon Challenge", "San Spade" and "Sherlook Holmes".

I want to be an inventor when I grow up.

I have ralted lots of interesting plaees. I wish that I could Fist Mexioo.

If I could have two wishes cowe true I would wish for a bleger home and a new 1949 Ford. Also I wibh we had wore money and that I had savinge aooount.

\section{MARY SUE-LEADER}

I have mother and father. I have three aunte, three unelea, two grandmothers and one grandfather. My father's rather aled berore I wa born. I have one brothor named Jimate.

On Wednesdays I to to a Grl soout meoting and then to my danelng olase. On Mondays and Thuradays I take plno leceons. The other days I usually play with my friends. Bometimes I go to the sovies.

At howe I vash alsher, put up the Brocerles and help mother oook. I somet1mes go to the $11 \mathrm{brary}$ for hor.

I take plano 10 sBons, toe and ballet danolng. 
I ILk to play bedminton and oard ganes.

I IIre to cook:

I want to learn to make sowe coll olothes and yam dol1.

My farort to book is Ieng Addams and my favorito magaxines are Storr Parede and Jeak and J111.

4y favorite rads programs are "Waltz Album" and "Blondle".

I 11ke to 100 runny morles and dog movies. I go to the movle about rive or plx times a year.

When I grow up I want to be a housekeeper. I want to have twine.

I heve Vialted Regnolds, Georgla where my grandmother and granarather 21ve. I w1ah that I could v1 a1t Mex100. I also would 11 ke to go to Boston and New York.

If I could have two wishes I would wh to 21 ve Wth my grandmother. I also wish that I could see a "Derby" .

\section{FRANCES-IBOLATE}

There are ten people in my family, my mothor. father, gxandfather, grandmother, Jaokle age 11, Dor1s Jean age 8. Charles age 6, twin staters 20 month old and I an 9 jeare ola.

I help around the house by taking oare of my twin sisters.

I do not take any lessons after bohool. I would love 
to take dunolng lessons.

I I1ke Bat Ball and Relay bost.

I I1ke to make doll dresses and I $11 \mathrm{ke}$ to make cake.

I want to learn to cook better.

My favorito booke are Hoedenug Laughs and Whegle and Winge.

My favorite raclo progran is "The Lone Ranger."

I I1re "Blondie and Degwood" and "Roy Rogers". "I go to the morlea about twice a reek.

I have visitod Alabana. I wi gh I could go to Florlda.

If I could have my wish it would be for a blayole. GLORIA-IBOLATE

There are six people in my tamily, my mothor, father, Bobby age 12, the twins age 8 and $I$.

After sohool I go to my plano lessons. I go to epeoch olass and danaing. I am a Gri soout.

I holp wy wother do the alshes on Seturday and Sunday. I help the mald clean sometimes. I love house work. I take danolng. elooution and piano lessons. Hother wants me to be a good singer. I love annoing. I an very eracerul.

On rainy days I make fudge. I al so 11 ke to make rudge ake.

I 11ke basketball, rolleyball and hop-sootoh. My 
favorito sports are owimalng, htking, camping and $\mathrm{Il}$ ohing.

4 favorite books are myateries and about famous pooplo. My farorlte magarine is Life. I Ilke $1 \mathrm{t}$ booause 1t telle about many people and 1 toahes you something. My favorite radio programs are "Dennts Day" and "Jack Benny". I $11 k e$ quiz programa and singing. I love to 11 stien to "Stop the Muslo".

I I1ke Walt D1aney's plotures best. I go to the movien on Saturdays and sometimes on Sundays.

I have vialted Ohicago. I went to the Zoo. My grandparents Ilve in Mland. I have been there. I went to sohool in New Jersey. I have v1 si tod Jew York. I wiah I oould go to Cuba and Callfornta.

when I grow up I want to be housew1fe and have ohllaren. I love bubles and I love to do work.

\section{DAVID-LEADR}

Wo have three people in my family, wy mother, father and $I$.

After sohool on Monday I go to Art Sohool. Tuesday I 80 to the Y,M.O.A. On Wednonday I play out of doors. Thureday I 60 to Soouts and Friday I 60 to the Y.M.O.A,

I 21ke to make model alrplanes, trains, boats and truoks.

I want to loarn to owim.

I 11ke beseball and footbell. Innalde I like rum and 
cheakers.

The books I I1ke beat are He Popper's Pengulng and whete in the Bkr?. The magazines I 11ke beet are Romure Dotenoe and Lte.

My favorite radio progrems are "The sereen" oulld Player"." "Quiz Keds" and "The Aldrioh Family".

The morles I 11ke are historloel morles and myster1es. I go to the movies ones week,

I have visited Mammith Gave. I want to go to the Grest Lakes.

When I grow up I want to be a ohemlat.

\section{FAYE-LEADER}

In my ramlly there are mother, father and I. After school I go home, take off my olothes and hang them in the oloset. I stt down and do my homework. Then I go out to play.

I take piano Iessons erery Baturday.

I of ton holp at home by washing dishea, and oleaning my room.

I Iike to make cookles and olothes pin dolls.

I would 11 ike to learn to owin.

The games I I1ke are Easy Konoy, ohookers and paper dolls. The sports I $11 \mathrm{ke}$ are beseball, football and roliegball.

My favorite books are The Wizerd of oz and wake belleve atories. My favorite magaine 19 Llfe. 
The prograns I 113e to Ilsten to are "Beulah".

"The Gavaloade of Amorloa" and "Tho' Btory Bour".

I 11ke wovies that are funny ach as "Life with Father". I also liked "Dog of Flanders" and "Lasale

Come Home". I go to the movies onee a veok,

I have Iisted Roohoeter, Minnosota whore we went to Kayo clinto.

When I grow up I want to be secretary to $\mathrm{a}$ blg morle operator in Follymod, Oallfornis.

If I had ay with I'd have a big plower barden with a 11ttie brook ruming through and gold $\mathrm{fleh}$ in the pond. 
1X ISAR AT SAHOOZ

In the Nay liseue of Youns Amevlos Renders there was an evaluation eallod "My Yoar At Behool". This gave the ohllaren an opportunt ty to mite more about "thelr tory". Ualng the asme ohllaren whose autoblographtes were revieved the teacher chose these parts for this paper.

NORVIN-ISOLATE

The eubjects I have enjoyed most thl year are delenoe, roding and art. If our class oould take one-day trip. I wish we coula go to the Firle range. If I oould 21 vo one sehool day agaln, it would be When we plajed the giris in sortball. If I could change one thing in acheol it would be art thmetio.

The game or sport I 21 ke better than any other 1: beoball.

Thit year I have tried to Improve tho way I play basketbell.

One thing I learned to make this your is model alrplanes. One thing I want to learn to make is a submarine'

When I have time to do anythine I please, I usunily go to a movie, or play.

often I holp at home by drying the dishes. 
At shool I 21 ke to work with one person.

When I got angey I ueually sey nothing.

I do not $21 \mathrm{ke}$ to tease. I don't oare when anyone teases me.

I have a pet because I Ilke pets.

The person I I1ke to work with at school is Jlmay, because I lonow him real well.

The person I Iike to play with Ia J1may, beouse I I1ke hin.

The person at our house that I Ilie to vork and play with

1. Johnny, beacuse he is ay brother.

If I could ohange one thing at home 1 would be to get

nore allowance.

When I Exow up I want to be a pllot.

Durtng raeation I w111 probably holp at home by gardenIng.

Some of the things I expeot to enjoy this summer ares reading, wiming, plonics, ratio, hiking, movies, gardening. colleoting stanes and nature study or biras. The elub or group I vill meot with regularly 18 Oubs. One good time with my fantily thi a oumor w111 be when we go awdwing.

The thing thet I am looking forward to this summer is ariming *

MARY SUE-LEADER

The aubjects I have enjoyed most thls year are 
mute, epelling, arithmetio and art.

One time I onjoyed singlng was when I was in the Fith oracte.

If our class oould take one-day trip, I wlah ve oould to Churehill Downs.

If I could 11ve one day at sohool again, It would be when I was in the Plfth Grade. If I oould change one thing at sohool it would bo Iunoh.

The game or apert I 21 le bet 10 volleybull. Thl g year I have tried to Improve the ray I play besketben.

One thing I learned to make thls yeux is Ilowers. Whon I have time to do anjthing I ploase I usualiy play inside or out. Often I help at home by helping my mother. At soheol I ILke to work with a row. When I get angry I uaually aay nothing. I do not like to tease. I don't onre if someone teases m.

I to hare a pet, becsuse I asked for one. The person I 12ke to work with at sohool 1s Phyl11., because the 18 ntoe and oooperatire. The pereon I I1ke to play with 1 s Mary because she 18 always ralr.

The person at our house that I I1ke to work and play 


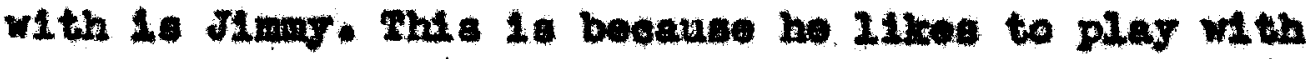
ne.

If I oould ahnge one thing at home 1 t would be oleanIng up my room.

When I Erow up I would Ilke to be a houserife.

The perwon I want to be $14 k e$ is my mother, beause she 1. ntee nother.

One thing I worry about is reading. Bowo of the things I expeot to onjoy this aummer are alming, hiling, novies, oolleoting sards, naturo study of trees, makes, birds and riowers. One good time with my family w111 be when we go to the country olub.

Whon wo go ewlmang I'II bave run with my frlends. The thing I'm lookting forward to moth of all 18 golng to oanp.

\section{FRANOES-IBOLATE}

The subjeste I have en joyed wost this year are arithesto and plays.

One tine I I1ked art was when I dxem a ploture of a do. If our olase oould take a one-day trip I wish we oould 6o on a pionio. If I oould 21ve one achool ang aguin $2 t$ would be at Ohretatmat. The gane or spert I $11 \mathrm{ke}$ bet is oornorball. One thing I learned to make this yoar it flowers. 
Whon I have time to do angthing I want to I usualdy Bo to a morle:

At sohool I Ilke to work with one person. When I get angry I say nothing. I do not $11 \mathrm{ke}$ to tease. I don't care when someone teases me.

I do not have a pet, beoause there 1a not room. The person I 11ke to work with at sohool $1 \mathrm{~s}$ Mary sue. because he is kind to $\mathrm{mb}$.

The people I 21ke to play with at home are my s1sters. When I grow up I would 11ke to be a danoer. The perseon I would like to be 21ke is Mary sue beoause she 18 sweet. One thing I worry about is reading.

\section{FAYE-IEADER}

The subjects I have onjoyed most this year are h1story. Beography and ar1 thmetio. One time I snjojed art was when I drew a Clean-Up Poster.

If our class oould take a one-day trip I wish we could go to Loxington. If I oould ohange one thing at sohool it would be mualo. The game or aport I like best is batball. This jear I have tried to improve the way I play by dolng what others want to do. One thing I learned to make this year is a flower. 
One thing I want to Iearn to make is doll elothes. orten I help at hom by rashing atohes. Whon I have time to do anything I please I play. At sohool I 12ke to work with one pereon. When I got angry I ubually tell about 1t. I do not 11 ke to tease. I get angry when someone teasea ne.

I have a pet beosuse I 11 ke one. The peraon I 11ke to work w1 th at sahool 1 a Mary because the 18 very nloe. :

The peraon I 11ke to play with at howe 18 Bobby becaves he is so falr. The person that I 11ke to work and play with 18 ay mother. She is good to me.

If I could ohange one thing at home it would be wash12 g at thos.

When I grow up I want to be a veoretary.

The perwen I want to be 11ke 18 mothor because she 1. good and kind.

One thing I worry about is going out to play. Durlag racation I w1.2 probably holp my family IIx the Jard.

Sowe of the thinge I expeot to enjoy thit aummer aret arinuing, red10, movies and oolleoting rooks. One good time with ny ramily w11l be when we go out. The thing I an looking forward to most is this vaention. 


\section{OLORIA-ISOLATE}

The subjecte I have enjoyed most this year are solence, reading, mulo, gpeli1ng, art thetie, art, geography and handwork.

One time I Ilked solence was when we did experiments. If our cluss could take ane-day trip I wh we could ge to the country.

If I could IIve one sohool day agaln $2 t$ would be when we played sortball.

If I could hange one thing at sohool 1 t would be nothing.

At sohool I Ilke to work with one person.

When I got angry I uavaliy flght.

I do not 11 ke to tease. I don't eare when someone teases me.

I do not have pet because mother coen't want one ar round the house.

The person I 11ke to work w1th at sohool 1 a Mary sue because she helps are.

The peraon I like to play with 18 my slater because we egree with each other.

If I could change one thing at home it would be the p1110us.

Whon I grow up I want to be a houeencle. The porson I would Iike to be Iike $18 \mathrm{my}$ mother, because the is well 2 ired. 
One thing that I worry bout is the rlghts I have with my older brother.

During vacation I w112 probably holp around the houed by eleaning up.

I expect to onjoy awiming, plonias, hiking, gardening, colleoting stempe and nature otudy or birds and butterP21es.

The olub I w1ll go to regularly is my 0100 Club. I am looking forward to plonios and swiming. Uating the information geined from these booklet. the teacher was able to understand the ohlloren better. Sho galned an Inolght into tholr neods and problems. It cerved as a band betweon the teacher and the ohlld. The teacher knew when making a personal eoment about their Intereats and their howe I1fe would be nost advantageous. After studying these omses the writer saw that ahe could holp in many waye to bring come roognition to the 180lates. She cowld glve the a feeling of confldence in their work and oould make thom foel wantod. Continued practice in good human relations oowld do moh to bring these ohilaren from the isolate broup. 
DIscusstons of AUROBYocraphras

When the dutoblographles and the reports on "hy Year At Bohool" were completed the ohlldren used the varlous aubjeots from thom for disousatons. They read from the1r booke about how they spent thelr days, how they holpod at howo, tho ldnd of homes, tholr sam1210s, thair favorlto booke, magesines and radio programs, the trips they had taken, what they were going to be when they grew up and their withes. In the alsoussion about tholr school work they told more about why certaln subjocts were their favorites and what they thought they had galned from the year's work.

During those periods the teacher noted the improvemont in partielpation. Freryone read from hls book and -veryone ahowed an interest in the disoussion, alking queations of the other ehildrea and commenting on their fevorite booke and favorite radto prograns, They compered booke and seemed partieulariy delighted with the plotures thet some of the ohlidren had dram to 11luetrate thols work.

Here the tonehor noticed the greater interaction and the self confidenoe diaplayed by some of the ones who had been Isolates. Irveryone seomed to get muoh pleasure rrom these pertode. 


\section{PART IV}

\section{AOTIVITIES II THE OLABSROOK}


AOTIVITIBS II THE OLASSROOU

Sinoe the promotion of good muan relations dopenda on the good things that oome from the overy day IIring and working together cooperatively in the olaseroon. and oreating an atmoophere favorable to growth, the witer felt that thore were many actirities that contributed to this. Throughout the entire yoar an attompt was made to give the ohlidren a feeling of aoooptanoe and belonglngnege. Every ohlld wishos to feel that he is underetood and appreclated. Ho wants to be able to foel that he is froe to exproes hil oplnions, to perform in tho vay woth pleasing to him and to bnow that hil oontribution w11 be notthor laughed at nor ridiouled. It is posalble to oreate this kind of atmosphone. The teacher probably has a great deal to do with this in the begiming, but soen the elas takes over the lden and it beoomes an establiahed procedure with whioh no one refumes to oooperate. In this kind of atmosphere the olass originates the ldeas used in many instances.

One of the favorite cetivities of this group was the crametisation. Ihts was ahosen as a moans of evaluation mest frequentiy at the end of a undt. There vas - defint to aramatiation planned for each Fr1day. The chalman was ohosen and he plannod what ho wlehed to dramatize. On Monday he acked for the ones that he 
ranted in hIs aramatization to weet with $\mathrm{hlm}$ to $\mathrm{flnd}$ out the partis they wore to take. The teaher was never In these groups and only on raro oockalons did the ohalrman have to remove anyone from his play becauve of misbeharlor. Mang ohtldren ralted eagerly to be obosen for the parte and they were just as eager to be the ohalran. At the end of the year overy ohild had had an opportunity to be In many plays and wost of thow had offered to take oharge of one. Thls was i good way for the leolate to be Inoluded. Franees had ohoeon Jary Bue for hor firat oholoe for comittee work. She had an oppertunt to be chosen by hary sue for a part in a dramatization. Mary sue sald to the toacher. "I enjoyed having Pranoes in ay play. Sho cooporteted bett of any one." Ihen Praneed entered the room no one know hor volee irell enough to reoognize it during a voloe teating pertod, but at the end of the yoar sho had beon in soveral playa and showed a rathor good sonse of humow in acting out one of the parts, that of a oat. In sueh an atmoaphere the oleas oritiolzed the aotors In ouch a way that it seomed holprul to then. Jokmy was told at the begtining of the joar thin he was too anxious In his parts and overuoted. Hi developod into a rery $800 \mathrm{~A}$ wetor by the ond of the rear. Bo acla that one of his withes was to be an actor or a inger when ho grew up. There was alvers mush apprectation show of the asting. The teucher observed during these perlode that there vas 
much Intoraction anong the audionce al eo. They set tom gether. They al eoused the playe uring internisulon: and epened to enjoy then thoroughly. At the end of the

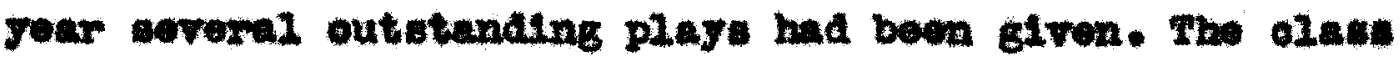
abled if they oould aes noveral of the good ones agatn. It was Interesting to note how ewoh ohild rewombered Which part he had taken and the seoond performenes was just as enjoyablo as the riret.

Those aramatisations were never regular plays. They were etomle oboen by the group or by tho ohatrman and the pame were nover written out. Thore was never any - Leborate noenery, but oconalomily the group declded that they noeded the tewoher" ohdir or that they noeded paper beardil or orown for the ohareaters. Somotines they brought old olothes ren home for geelal plays.

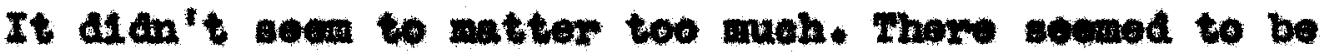
equal enjojment of the plage even though the audienee was roquired to use thoir Inagination. In the ovaluation of the joar many pupile 21 ated "giving plaje" as somothing that thoy bed 11ked.

Kany ohllaren woonod to galn a place with the other nembers that they and nover hold before, by their partielpation in these dranatsations. The reapeot nown for each ohild's oontribution ma outetending.

The use of Parohodran wa wother are wheh proved an exoellent way to reloase pent up enotlone. 
The writer made no attempt to annlye any of tho omotione chom. Whis mothod soemed to ut1I1se the oh12 '. nownal dealre for expreanton. In this way the oullaren used thelr whole bodlest they talkeds they indulged their natural love for pretending. This mothod holas no problem of keoping up a ohila"s intereat. In this group some of the aoting wast "At the Orodery". "At Howe in the Eventng". "Talking on the Telephone"; "Company for DLmor". "Father Goulng Homo

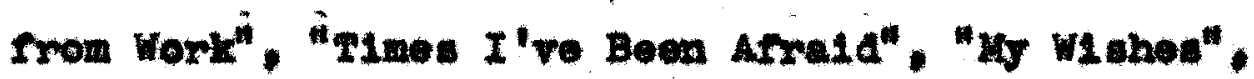
"At Sohool", "Playing with My Brother or siater" "My Pote". "My Firet Day in a Now Bohoel" and "Itew Ohizaren in the Nelghborhood". Sonetimes the soone vas set by the ohlidren and again 1 te wes juat spontuneous a.t1ag.

Payohodram 1s one of the new techniques in eduoation. It 2 seld thit the Impact of loaming by poyohodrand is woh that the pup1l often carr1es the momory of whe ocourred long after othor learnings have faded. The stuntion really begins after the olese know that comathing is to be performed and that overyone in the eroup may partiolpete. It seome thet the omorgenoy aspeot of the payohodrame is one of the aymanto factors $\mathbf{I}$

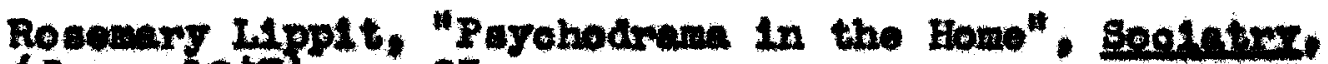
(Jume. 1947 ): $: 25$. 
In thl experlenoe. Paychodran produees a self awarenese distinet froin welf conselouaness. The partlolpant has the audienee riempolnt as well as that of the aotor. Many onlightening insights wore galnod by the tosoher into the Ilfe of the ohllaren. As they became more free in their expresetion thore wore more volunteers. Ho ono was ovor forced to eot. Eromyone knew that the performances rere not supposed to be pertect. One of the most interesting sessions was when the boys and Giris soted out the part of thatr fathers coming in from work. Aa whole wost fathors apposred to be rather omupy and not inolined to be bothored with their fanilles. many of then shoutlng for thelr cinner and the paper. The onlidren seomed to enjoy seelng how other rathers aoted. It probably gave than an opportunlty to obserre the similarities and the alfrerenees. Orten 1 t is eacier to endure something if one knows that this is not nomothing unknown to othora.

One of the boys told his mother that he gueseed that was why the teacher had never marr1ed - the way that fathere aotod.

Thi. role playing proved a very rolaxing experionee for the obilaren and also for the tecoher. It eerved for better underatending on the part of the tescher.

One of the boys roluntoered to bring his batters radio to wehool. Sometimes the olane llatened to the 
good muslo brodeants. Orton they worked with olay. oolored ohalk, tinger palnt, orayone or any other modis whilo they wore 21 stening to tho mus10. Somotimos a subjoot was given for the art work. Orten the olasa ohose to drex to the mulalo. Aftor the broadoaste the ohlldren disousued how the mullo had made them foel; whethor it bolpod them to rork better, whother it interfored with thelr oomentention with the othor members of the alass. Host of them agroed that thoy oowla work well with mus10. Thes thought that the quiet musie helped than to be more qulet also.

Gamen of all kinds, Indoor and outdoor, can ochtribute to eelf control and to the realsiation of the Importanoe of good toan work. Thls Is an area where cooperation counts mot. Gamos give a ohnee for some of the ohlidren who oannot exoel in acudemio flelan to gain a place for themelves by their ablistles to throv - ball or to run. Good iportemanuhip doem't develop if the Individual never has an opportunity to play with othore.

Whon ohlideren are at oase and foel hoalthy, happy and sooure within thomselves the ohunoss for attitudos and boharior. conalstent with good human relations

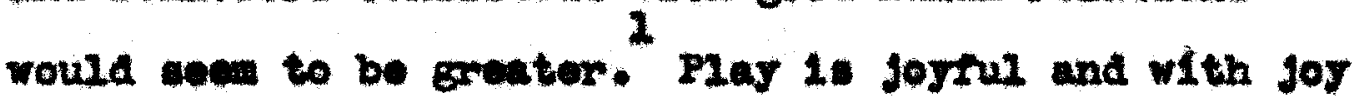

$I$

Del1. Huswey. "The PLay Route in Human Reletlone".

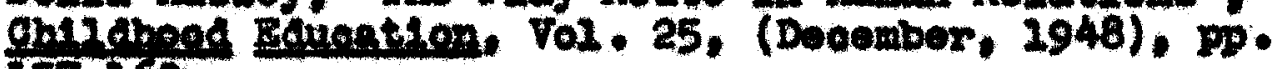
157-160. 
comes well belng and harmon, One of the b16 problem In buman relationi today 1. how to make people real "good" about other peoples In play ohliaren are at ease and get to know oach other in a way that no othor aren ceens to provide. Rhythm and danoe sotiv1t1es play an impertant part in the play of ohilaren. The oreative opportunitien offered in danee inorease apprealation in muslo and artiatio forms. Ohllaren in thelr reapones to musto are froe and unself-conselous. The danes can contribute to the art of riner and better IIving and thu bring grester sutiefaetion to the in-

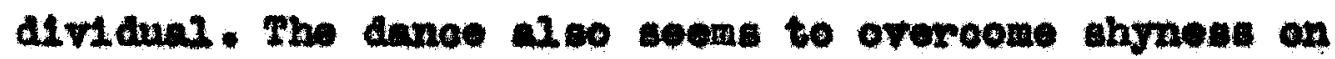
the part of the ohlidren. It ahowe them some of the soetal amontites.

Thls group of ohtlaren 20oked forward to the danes perlods held each weok. Thts was partiolpated in by overyone. At the end of the year some of the ohlidren were really good dancers, but meat of all overyone had a good time.

There secmed no better way to got a eroup to oooporate then to plan a trip. Since this olass was making a otudy of milk the toacher arranged for then to 80 to a dalry and to a farm. Some of the mothers volunteered thelr ears. Tht gave good opportunity for the ohllaren to onjoy a part of their bohoel any with some of the wothers. The trips proved very instruetive. They aleo provided 
weny ohanoes for disousslons before and after, for group planning and tor lote of tun by all obpelaziy when the gulde let the ohllaren foed the baby calves. When one 1s haring fun 1t is imposalble not to have a good roeling for everyone.

One of the cotivities onjored most by the eroup ras, "Talent Bhor". The tecoher was surprised to rind how many ranted to alng, to play the violin, the plane, the curaphone and to do intetions. Beromal quartete wore formed. One ohila aoted as mater of oeremonies. The ravorite inttations were "Red Skelton" done by Bard and "Vaughn Konroe" cone by Johnay. There was always muoh applause fron the audionse and the ohilaren seemed to glow fon the aoduin given by their elasmates.

At varioue times during the year bobby whows were hela mith eneouraged the ohlidren to have nome worthwhis wotivitios to carry on outelde of wohoel. Bach time there was wore intoreat and wore hobbled wore diam played.

All of these aetivition wore entered into with

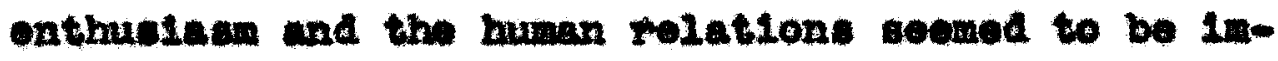
proved bobause of then. 


\section{PART V}

SUMARY AND COHOLUSIOHS 


\section{Sunourex}

Thle papor bas tried to show wome of the ways that may help to produce a classroom altuation conducive to the best covelopment of the ohlldren. This would seem to cowe only through an onviroment whtoh was rolaxed, free from disolplinary tonulon and above wll one that was rriendiy, In oxder to nohlowe this the teacher must want to bow why the ohild nisbehaves or aots as ho does rather than how to pund ah. The atmosphero of rals play and mutrual roppot onoe eatrablishod makes posalble an approach to toleranee, boneaty, courteny and other attributea,

The tosoher must make a roul offort to undoretand and approalate the ohlldron and the parents, and to aooopt them as they are.

Thore is groat value in having overy ohild particlpate no matter what his lovel of ability or his fleld of interest. In planning the toweher must oonolder the offaot of the ourrioulum upon oharacter and personality as wuch as the Importano of the subjoot matter. Toduy the good teachor ainimisos hit authority. He is intorented in and aoopsts his pupizs as indiriduals. He 1. Interested in giving thom Exoater opportunitles for oxpression. He holpe then to gain Inalght about thomaelves.

Norman Fenton quotes Trom the Third wht to Fouse Con- 
feronoe on Chlla Hoal th and Proteotion in 1929 the following dorinition of good wontal houlth!

"The adjustment or Individuala to thomselvo and the world at large with a maxima of efreotive-

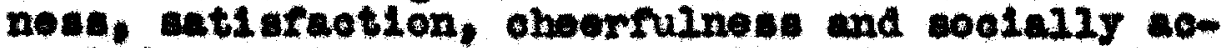
oopted behar1or. and the ab111ty of raolng and cooepting the realities of IIfo."

\section{concLustons}

In a mall way this was what the riter attempted to ecoompilah with the group in Room 12. It Im't posstb10 to meacure the cuceese or rallure of the gear's work jot, but some of the oraluations of thatr work given by the ohliden at the and of the year rere interesting. Franoes, en 1aglate, eald, "I've learnod to $21 \mathrm{ke}$ ay thole self."

Bard ald. "I think I'm leas gripy now"

Barbara. "I'n not so ahy now. I con't mind getting up in fromt of the azess "

Bobby Loe, "I'm a better iport."

Hubert. "I"n trying to wet not so tough."

Phrilis. "I'm trying to atop thinking I"In so pretty."

Faye, "I've leamed to ahare with others."

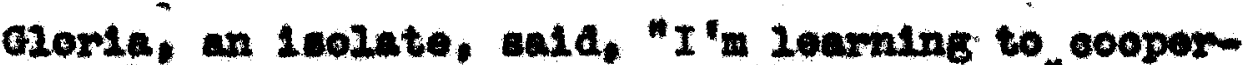
ato. People are be glming to $11 \mathrm{ke}$ mo more."

After vorking on the papes and putting down the experienoe the miter agreed that good humen relations

1

Hownan Fonton, Hontel Hratur in Bobnor Prantine. Oel1fornist Stanf ord Untreraty Preas. 1943. P.3. From the Third White House Contorenes on Ohild Bealth and Proteotion in 1929 . 
are Ienrned reaotions. 
BIBLIOCRAPEY 


\section{BIBLIOCRAPHY}

Booka

Axilno, VIrginla, Pler Thorepx. Boston: HoughtonMirrin Companj. 1947 .

Boynton, PaW, John W.Charles and PhL11p Harrian,

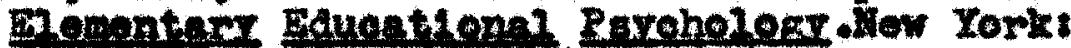
Prontroo-Hail Ino *. 1945 .

Breokemridge, Marion E., and E. Lee Vinoent, Gh1, Derelopment. PhIledolphta: W.B. Saunders Do.e 1949.

Fenton, Nornan, Kontal Hratene in Sobool Breot1os. Oallformi: Stanford Uniforaty PTons. 1943.

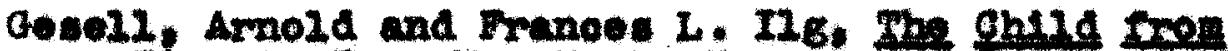
Dire te Ten. Hew Yorki Harper and Brothers, 1946.

Orifr1n, J.D.X, B.R. Layeook and W, LIne, Kenth. Brstiene. Oinelmati: Anortoan Book Company. 1940.

Hartanen, Gertruale and Ans Shumaler. Grest1re Bromeat10n. New Yorkt E, Hale and bospany, 1939.

Dein, D.B., Hontul Hratone. Iew Yorkt Henry Holt and Company, 1944.

Loe. J. Murray and Dorris May Loe, The Oh11d end H1e Guroloulw. Fow Yorki D. Appieton-Contury dompany Ino.. 1940.

Maguira, Bavard R., The Groun Btudx g7an. Now York: Oharles Seribner's Bons, 1926.

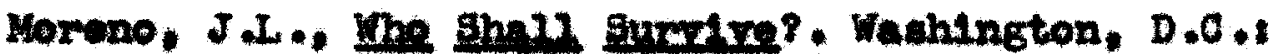
Nerrous and vental Diwease Publiehing Company. 1934.

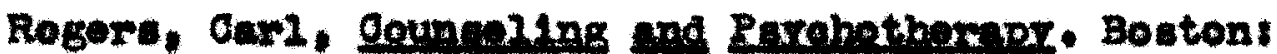
Houghton-Hifilin Company, I9ka.

Rogere. Garl. Ihe oumtael hentment of the Broblem onv14. Hei Yorkt Houghton-rarfin Oompany, 1939.

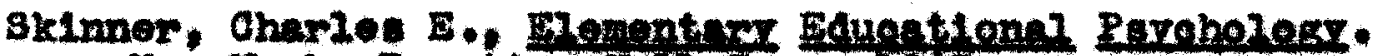
Now York: Prent160mall Ino

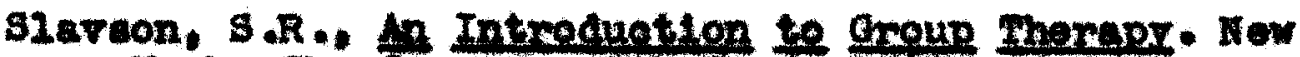
York: The dommomearth Fund, 1943 . 
Travle, Lee Bdrard, and Dorothy Baruoh, Rensond

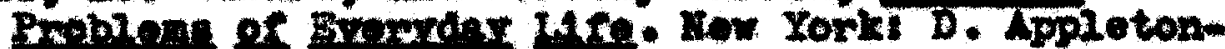
Eontury company. 1942.

W1ttenberg, Rudolph H., So You Want To Here Reople. Now Yorkt Ascoolation Irosi, 1947.

\section{Rovionten:}

Baron, Denis, "Montal Heal th Obaraotoristios and C1aba-

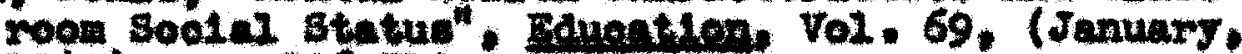
1949). DP. 306-320.

B1x2er, Ray H., "Treatment of A Reading Problem Through

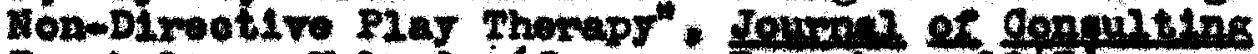

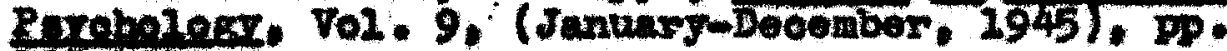
105-151.

Beland, Mary O., "the Une of Therapy as an Bropertenoe in Crowth Within the Strueture of a Ohild-Gutdanes olinle" Hontel Hratent. Vol. 23, (Apr11, 1949). p. 271-279\%

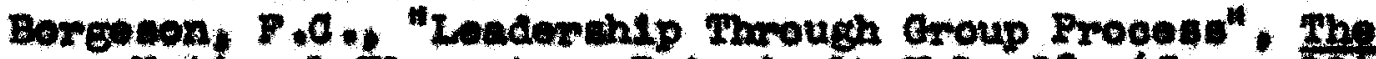

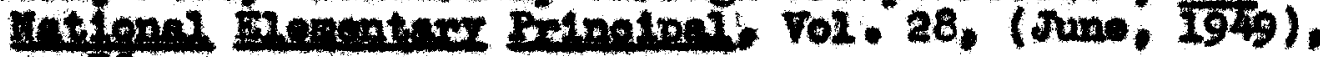
p. 30.

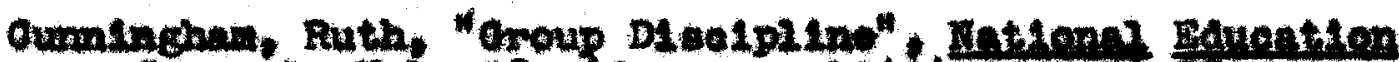

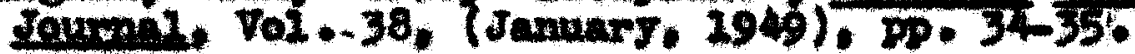

Darle, Ruth. "Group Thorapy end Boolal 4ooeptenoe in a

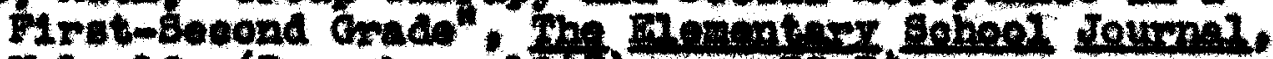
Vo1. 10, (Deosmber, 2946), DP. 32-34.

Frank, Lamence K. "The OrLentetion of gfucation to the Iromotion of Montal Hretend". Menter. Bredene. Vol. 23. (Ootober, 1939), p. 530.

Gineburc, Bol WLener. "Soolel Selonee and soolal Aotion"

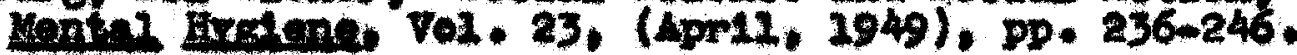

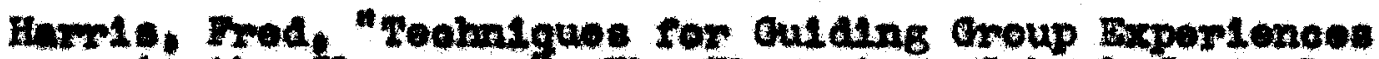

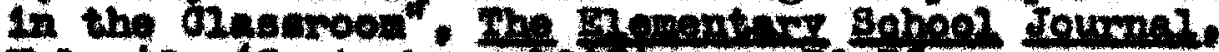
7o1. 49. (Beptember. 1948), D9. 32-36.

Hussey, Delle, "The Play Route in Human Rolations" "Ohilehed EAmention, Vo1. 25, (Decomber, 1948), Pp. 157-160. 


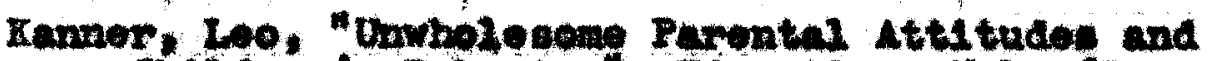

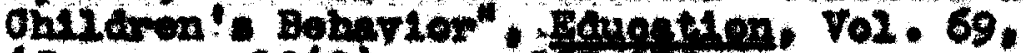
(Jaman, 2949), pp. 263-276.

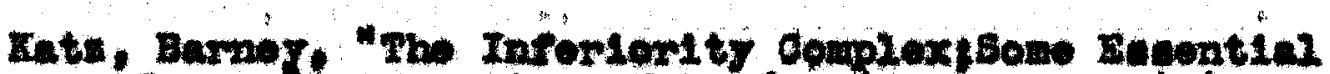

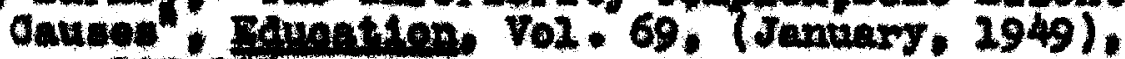
pp* 293-295.

Mar. Wullen Veld, "Role Playing as a Teahtas Mid".

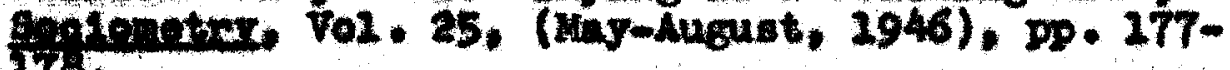
178. :

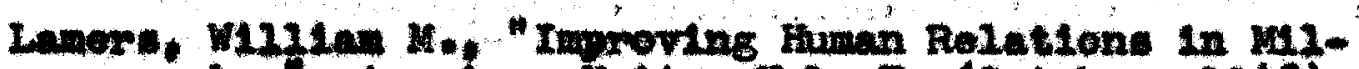

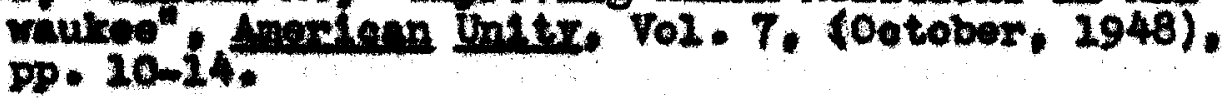

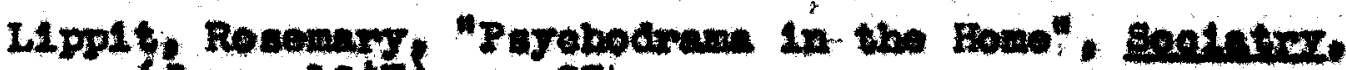
(Jine, 2947), . . 25:

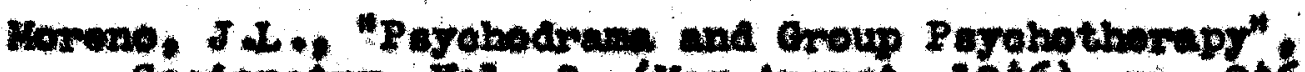

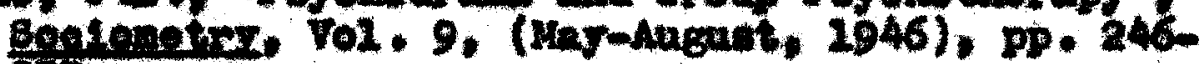
25s.

Northray, Wary L." "Personel1ty and Boolonetrie statu"".

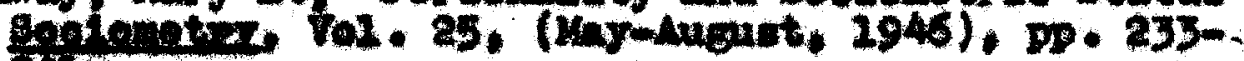
art.

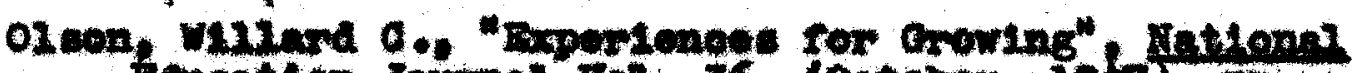

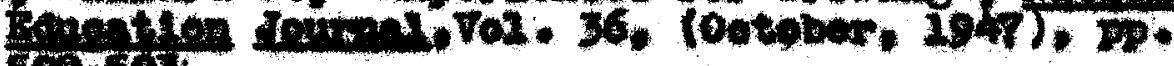
sosesh

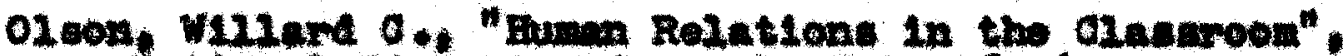

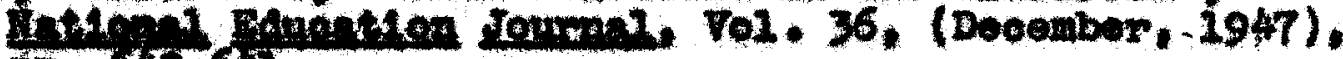
D. $61006 \mathrm{a}$.

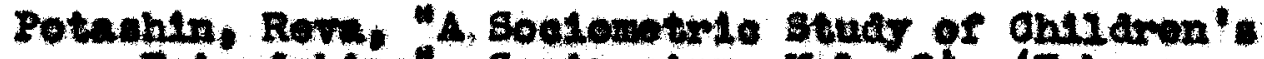

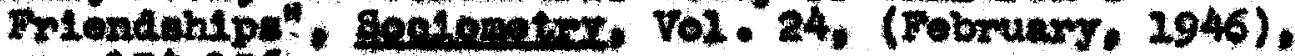
Pp. $154-156$.

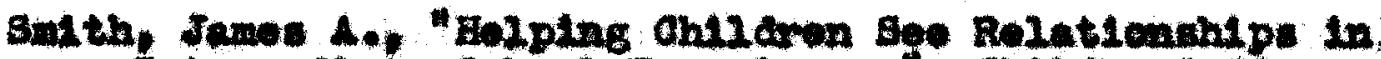

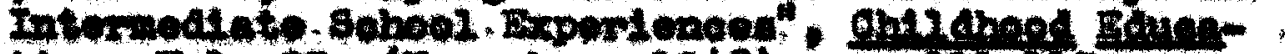

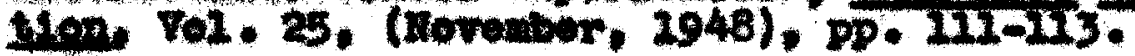

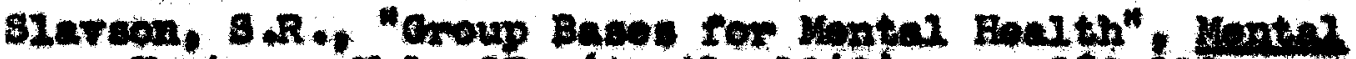
Eredene, Vol. 25, (Apri), 2945). p9. 260-292.

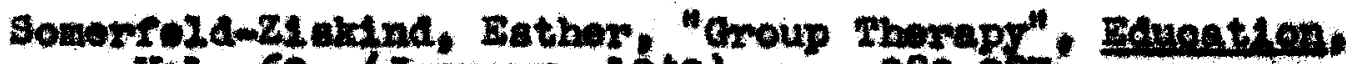
7o1. 69, (Jamary, 2949$)$. pp. 280-267: 
Stott, Lelund, "Mogtel Heal th and Dovelepmontel HFGlear". Edungttor. Vol. 69. (Jenuary. 1949). pp. $272-274$

Syouds, Perelval M., "Eduoation and Payohotherapy".

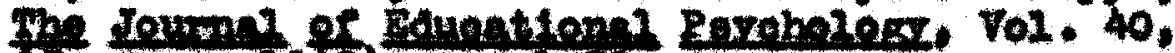
(rentary. 1049$): 50 \cdot 1-32$.

Thorpe. Louls, "The Development of Battonal Maturity".

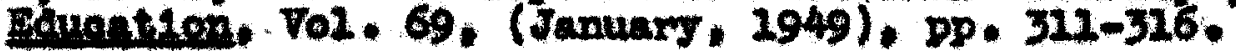

\section{Bempints:}

Bulletin of the Aseodiation for Ontlahood sduostion. Adrenturen in Bungn Rerstiont. Wabington, D.0.:

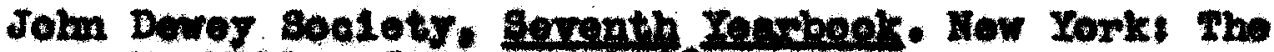
undizien cempeñy, 2048 .

Jennings, Helen Hall, Bophentror in Group Relationas

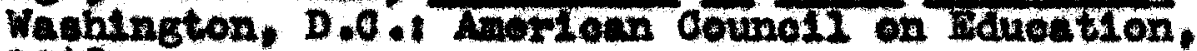
1948.

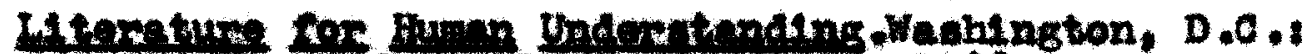

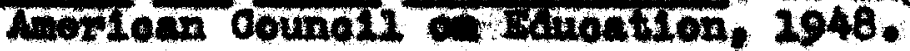

Bational Edueation Aweooletion, Department of Bupaxreere and Direetore of Instmuetion, yortal Whith in the ginenom. Thirteonth Yoaxbook. torhington. D.C.I its bepartment of supervisors and D2reotors of Instruotion, 1940.

The National Comal ttee for Nental Hyetene. Ino * Indertending the ght14. (Apr12, 1947), Hew Yorkt

Lotumen

Jonninge, Helen Hall, "Beolometry", Louterille Haze Heh sohool, Nay 22, 19496.

Ke110y. Dr. Fob10. "Fumannentel Prinetples of Humen Relations". Ontrexalty of Loulorille, July, 892949. 